\title{
Some Rare-Element
}

\section{Mineral Deposits in Mainland China}

By K. Y. LEE

CONTRIBUTIONS TO ECONOMIC GEOLOGY

GE L L G I C A L S U R V E B U L L E T I N 1312-N

A digest of the published literature, - including interpretations of geologically similar environments in mainland China

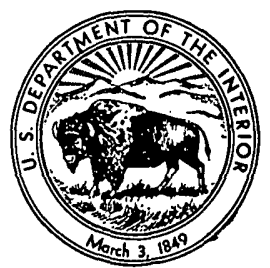




\title{
UNITED STATES DEPARTMENT OF THE INTERIOR
}

WALTER J. HICKEL, Secretary

\author{
GEOLOGIGAL SURVEY
}

William T. Pecora, Director

Library of Congress catalog-card No. 74-607065

For sale by the Superintendent of Documents, U.S. Government Printing Office Washington, D.C. 20402 - Price 25 cents (paper cover) 


\section{CONTENT'S}

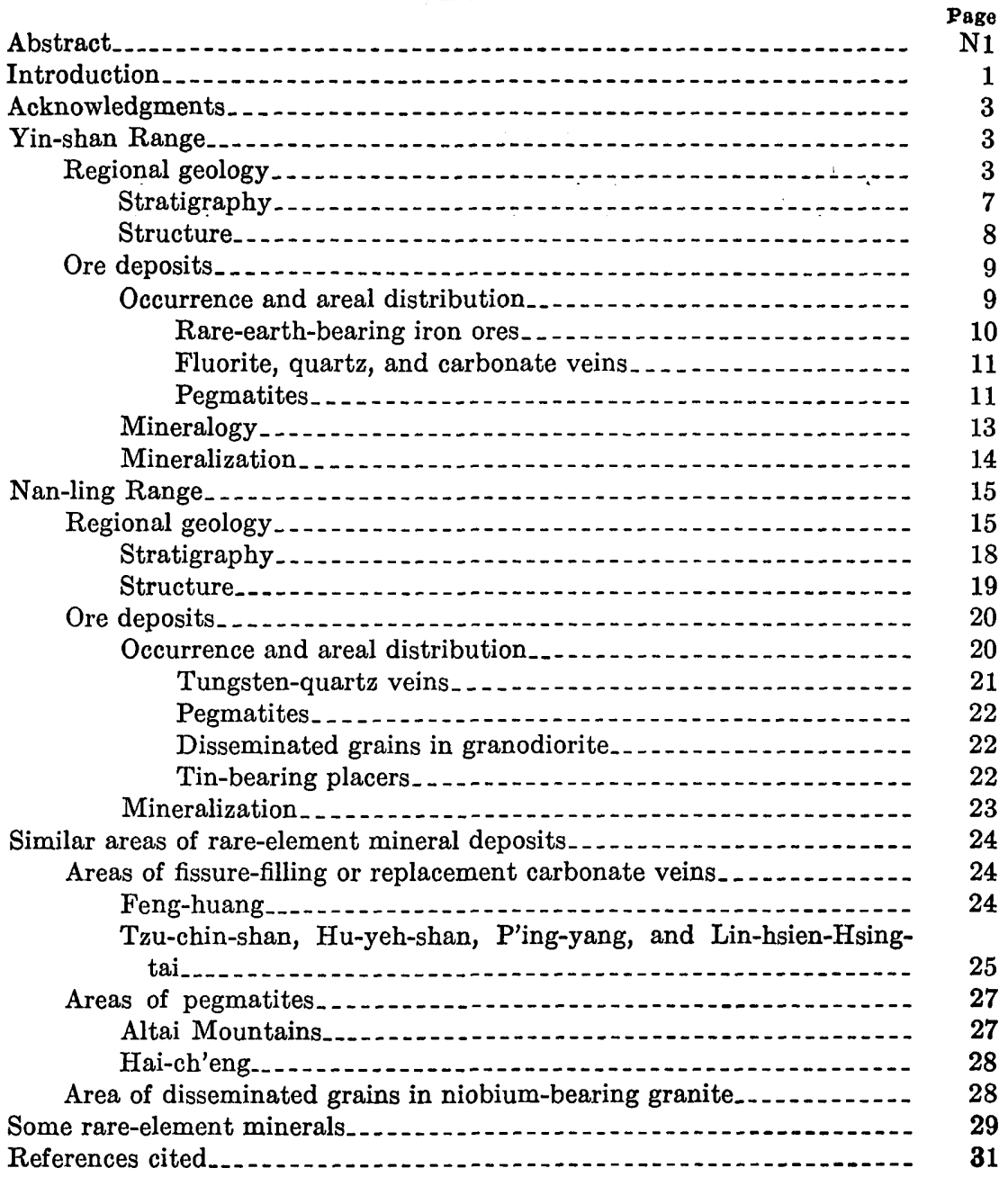




\section{ILLUSTRATIONS}

Figure 1. Index map showing locations of some rare-element mineral de-

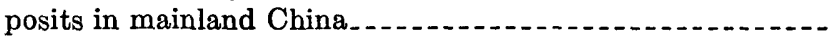

2. Generalized geologic map of the Yin-shan Range, north China -

3. Generalized geologic map of the Nan-ling Range, south China.

\section{T A B L E}

TABLE 1. Chemical composition of some rare-element minerals from Page

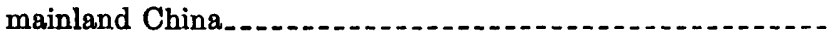




\title{
CONTRIBUTIONS TO ECONOMIC GEOLOGY
}

\section{SOME RARE-ELEMENT MINERAL DEPOSITS IN MAINLAND GHINA}

By K. Y. LeE

\begin{abstract}
This report is a summary of the rather fragmentary published literature on rare-element mineral deposits in mainland China. In the Yin-shan Range of north China these deposits occur in tabular iron ore bodies, in fissure fillings of veins, and in pegmatites. The iron ores and veins were emplaced in upper Precambrian limestone and dolomite, and the rare-element minerals consist of aeschynite, baotite, beiyinite, fluorite, monazite, niobo-aeschynite, oborite, parisite, and other cerium- and yttrium-group minerals. The pegmatites occur in lower Precambrian gneiss, schist, and granites, and the rare-element minerals are allanite, ampangabeite, apatite, beryl, bröggerite, chrysoberyl, columbite, euxenite, fergusonite, ferrithorite, fluorite, ilmenorutile, finingite, monazite, samarskite, sinicite, sphene, tantalian aeschynite, thorite, toddite, tysonite, uranothorite, xenotime, yinshanite, yttrotantalite, and zircon.

In the Nan-ling Range of south China the rare-element minerals occur chiefly in tungsten-quartz veins, in tin placers, and as disseminated grains in granodiorite. The veins are of hypothermal and less productive hydrothermal varieties, and were emplaced in fracture zones of Mesozoic granites and preDevonian metasedimentary rocks during Cretaceous orogeny. The principal known rare-element minerals of the vein deposits :are beryl, fluorite, helvite, monazite, xenotime, and uranium and thorium minerals. The disseminated grains in granodiorite include allanite, fergusonite, monazite, thorite, and xenotime. The tin placers contain monazite, phosphuranylite, and uraninite.

Other areas of rare-element mineral deposits in mainland China are postulated on the basis of similar geologic environment and mineral association. The cerium and $y$ ttrium groups and thorium are the major rare elements in the vein deposits of Shansi and Hunan provinces and in the pegmatites of the Altai Mountains and Hai-ch'eng areas. The yttrium group, thorium, and uranium are the principal rare elements in the Kwang-hai niobium-bearing granite.
\end{abstract}

\section{INTRODUCTION}

The rare-element mineral deposits of the Yin-shan Range, north China, and the Nan-ling Range, south China, are well known (fig. 1). They occur in tabular magnetite iron ores; in fissure fillings of fluorite, 


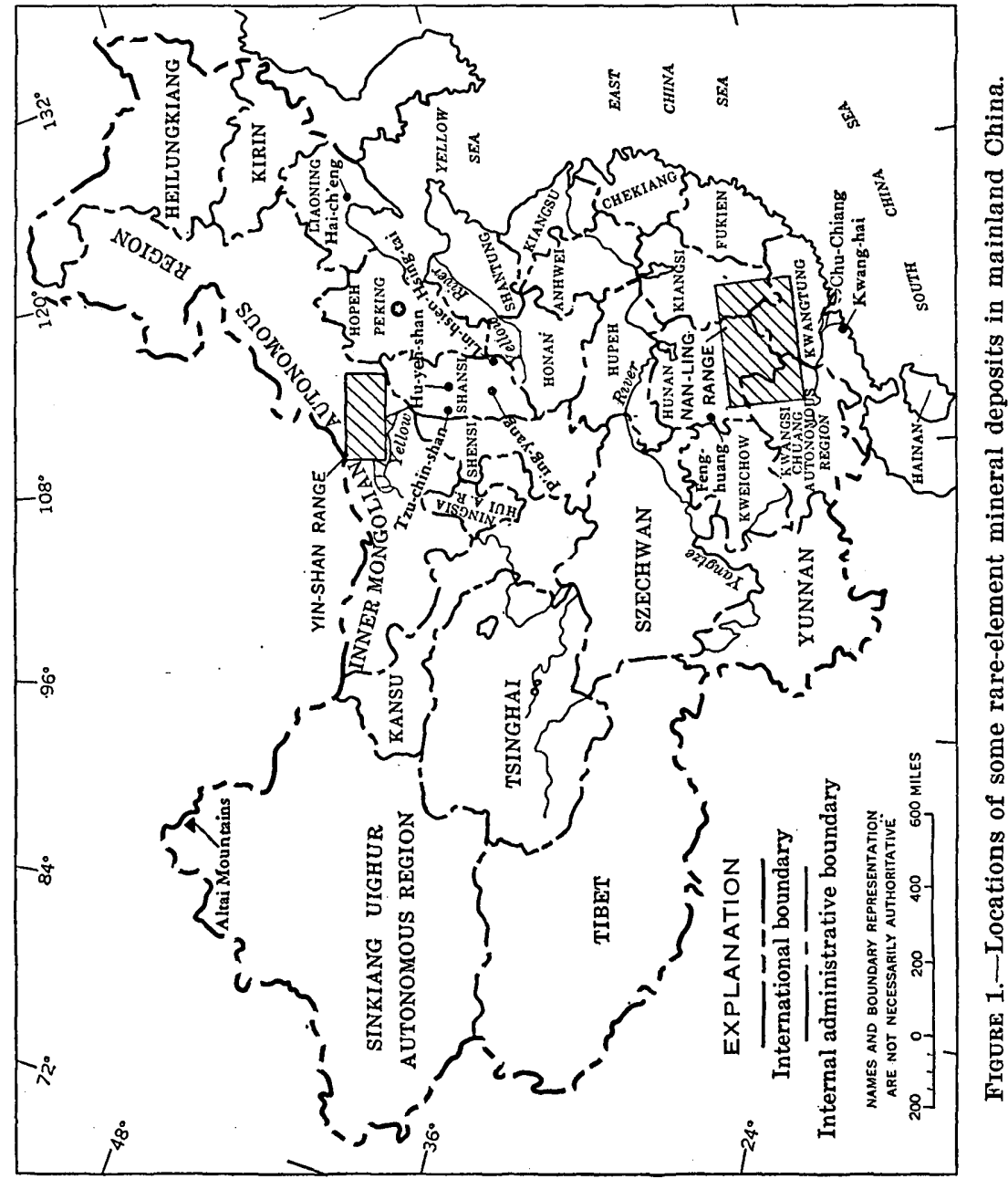


quartz, and carbonate; in tungsten-quartz veins; in muscovite, biotite, and biotite-muscovite pegmatites; in tin placers; and as disseminated grains in granodiorite. The cerium and yttrium groups and thorium characterize deposits in the Yin-shan Range. The yttrium group, thorium, and uranium are the most common rare elements in deposits of the Nan-ling Range (table 1). Several similar areas of rare-element mineral deposits have also been studied.

The purpose of this report is to provide a digest of the published literature for each type of rare-element mineral deposit and to ascertain the mode of occurrence in relation to the mineral association and geologic environment. As information in the literature is generally fragmentary, the writer has added interpretations of some deposits.

Because several of the minerals listed in this report are named for localities in mainland China and are generally unfamiliar to Western readers, a section in which these minerals are described has been included (p. N29).

\section{ACKNOWLEDGMENTS}

I am grateful to the following persons in the U.S. Geological Survey : L. D. Bonham for encouragement and advice during my research, Michael Fleischer for suggestions on mineralogy, and J. C. Olson and J. W. Adams for technical review. The research that led to this report was supported by the U.S. Department of Defense.

\section{YIN-SHAN RANGE}

\section{REGIONAL GEOLOGY}

The Yin-shan Range (figs. 1,2) is in the west-central part of the Inner Monogolian Autonomous Region and separates the Mongolian Plateau on the north from the North China Plain, dissected mountains, and hills on the south. The range consists of Lang-shan, Sheiten-o-la, Wu-la-shan, and Ta-ching-shan, the last three of which are included in this discussion. These mountains, separated by broad valleys and basins, trend east-west and attain altitudes that range from 1,500 to 1,900 meters. They are structurally a part of the eastwest Inner Mongolian anteclise (Academia Sinica, Institute of Geology, 1959, p. 23). This landmass has been stable since the late Precambrian. It is flanked by the Mongolian geosynclinal fold belt on the north and the north China platform on the south. The basement rocks are widely exposed Precambrian metamorphic rocks penetrated by granite and pegmatites. A sporadically exposed marine sedimentary sequence of Paleozoic rocks unconformably overlies the Precambrian metamorphic rocks. These Paleozoic rocks are generally intercalated with volcanic rocks in the lower part and penetrated by igneous rocks. 


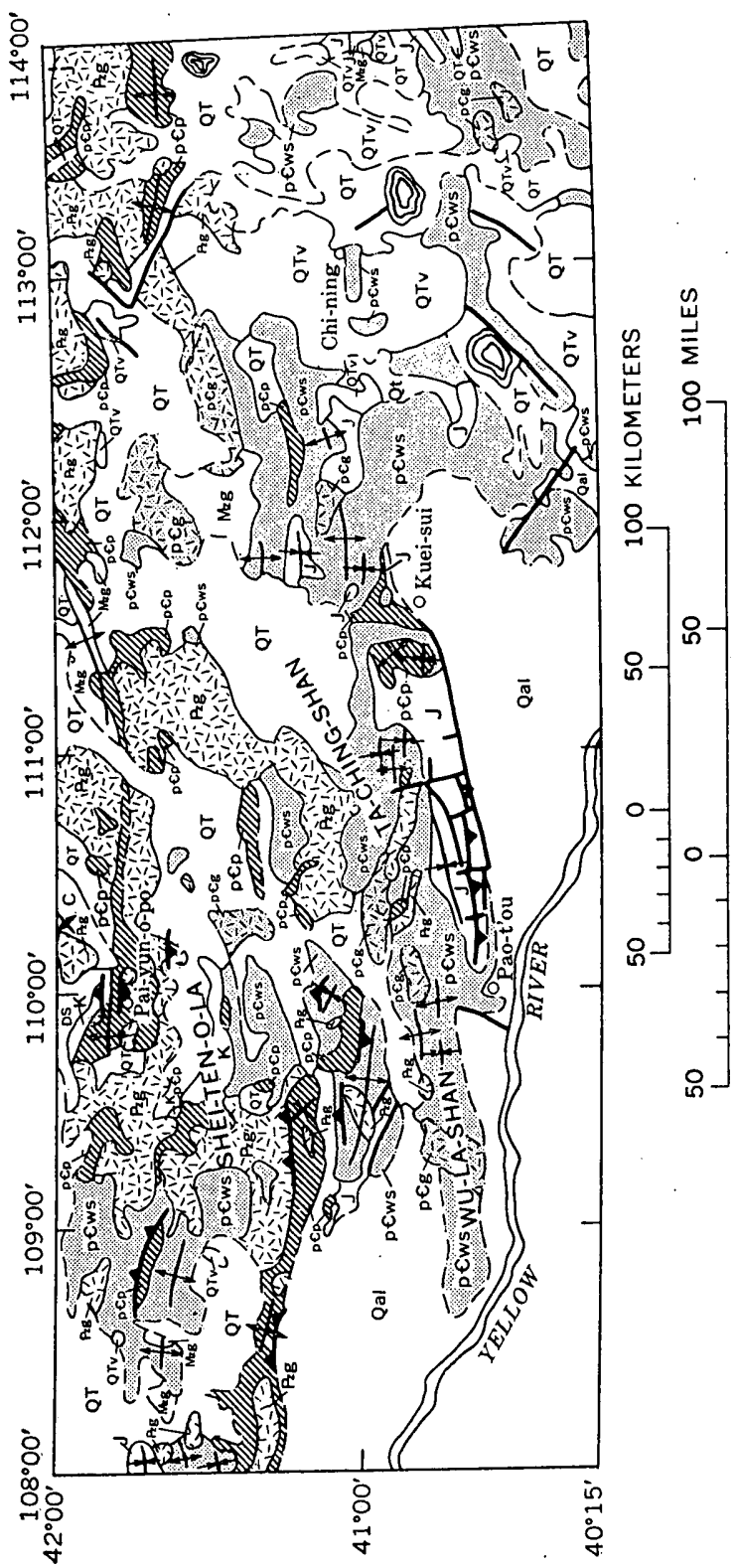




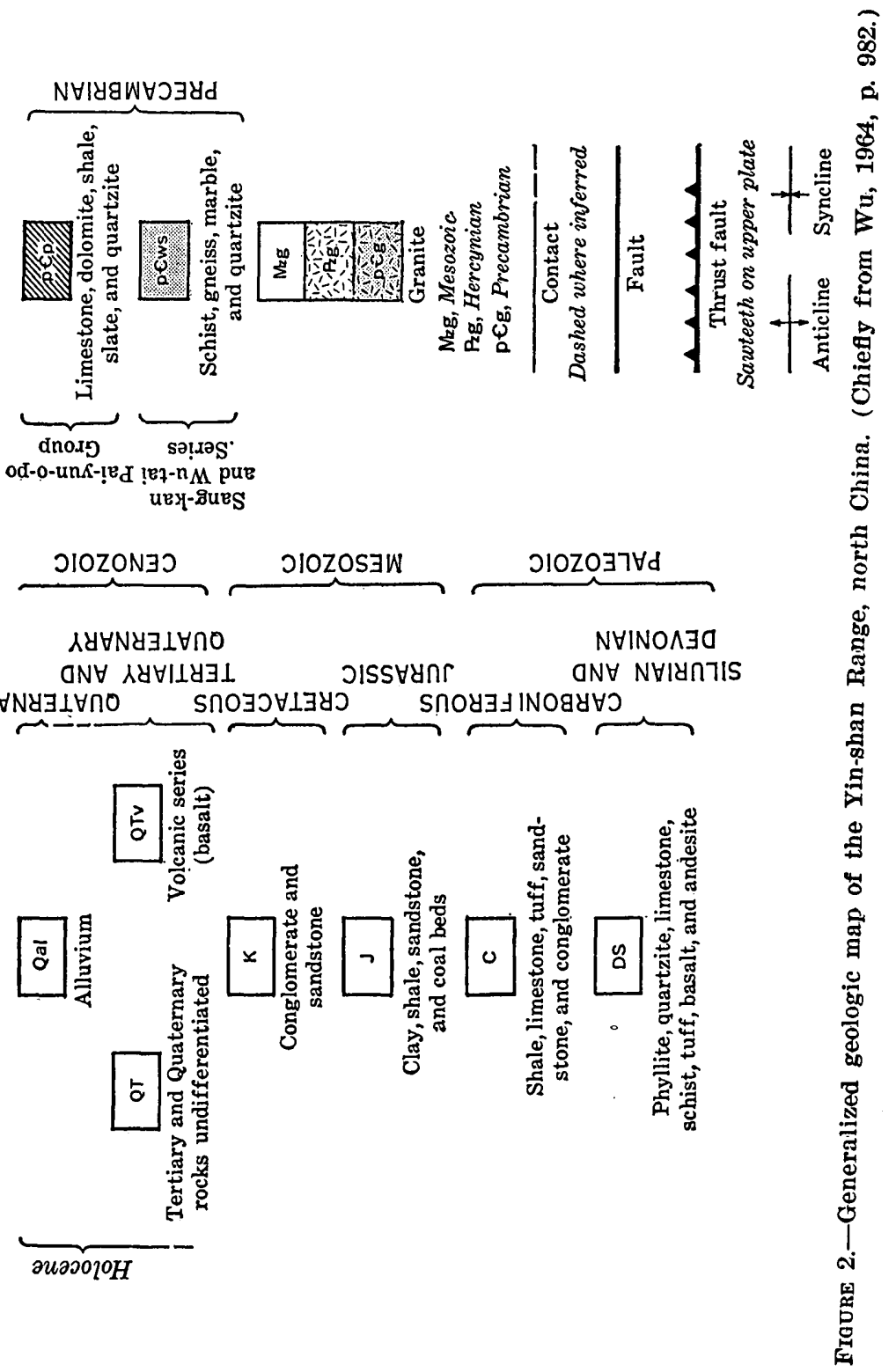




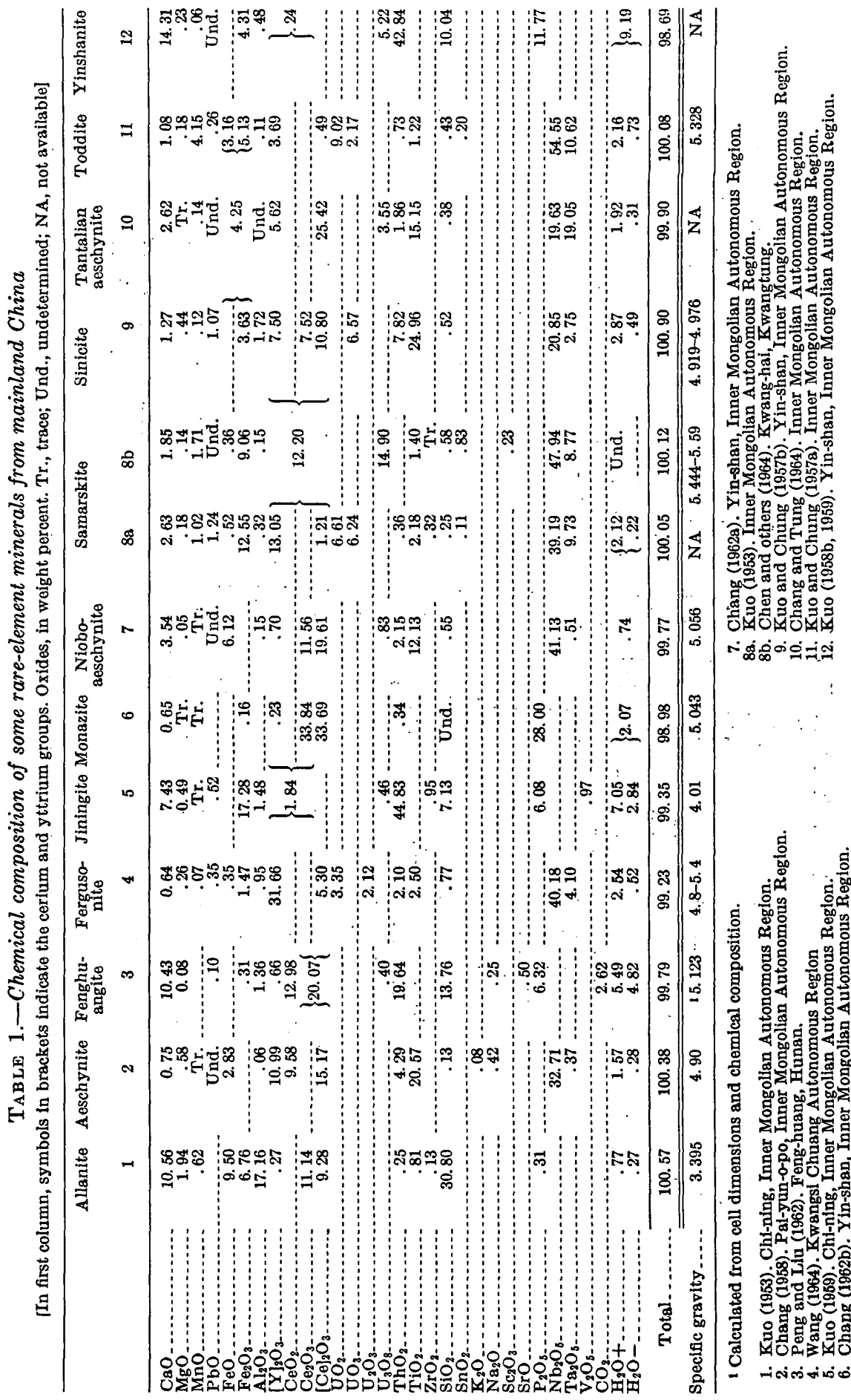


In addition, a continental sedimentary sequence of Mesozoic and Tertiary rocks covers the older rocks in most of the lowlands. Most of these clastic rocks are capped by late Tertiary olivine basalt flows. Loose Quaternary alluvial, eolian, and glacial deposits conceal the bedrock in scattered areas. East-west folds in the bedrock range from broad to tight and overturned. The bedrock is cut by many east-westtrending deep-seated block faults, thrust faults, and tear faults.

\section{STRATIGRAPHY}

The basement rocks consist of lower and upper Precambrian metamorphic complexes. The lower Precambrian rocks form the core of the Inner Mongolian anteclise and consist of eugeosynclinal sequences of the Sang-kan and Wu-tai Series (Academia Sinica, Institute of Geology, 1959, p. 24). The Sang-kan Series is made up of pelitic, siliceous, and calcareous biotite schist; hornblende schist; marble; granitoid gneiss; garnet-biotite gneiss; and augite gneiss; these are intruded by granite and pegmatite. The Wu-tai Series is made up of mica schist and sericite schist, which are intercalated with banded and laminated magnetite layers containing quartz and homblende aggregates and with volcanic rocks; this series is intruded by granite, pegmatite, and hornblendite (Lee and others, 1957, p. 260; Academia Sinica, Institute of Geology, 1959, p. 24). The Sang-kan and Wu-tai granites, which occur as sills, dikes, and stocks; are even grained to porphyritic and consist chiefly of orthoclase, microcline, sodaplagioclase, quartz, biotite, hornblende, and some hypersthene.

Lower upper Precambrian rocks are represented by a miogeosynclinal sequence of the Pai-yun-o-po Group, which consists of quartzite and slate in the lower part; calcareous quartzite, siliceous and clayey limestone and dolomite in the middle part; and slate that contains interbeds of quartzite in the upper part. This group is locally intercalated with hornfels and mica, sericite, rutile, cordierite, and garnet schists (Lee and others, 1957, p. 245-253; Young and others, 1957; Academia Sinica, Institute of Geology, 1959, p. 24 ; Ting, 1933, p. 54). Total thickness of this group is 3,010 meters in the Pai-yun-o-po area. Upper upper Precambrian rocks are made up of quartzite and shale in the lower part, siliceous limestone that contains oolitic hematite layers in the middle part, and siliceous limestone in the upper part. Thickness ranges from 400 to 700 meters. These rocks occur sporadically along the southern flank of the anteclise.

The Paleozoic Era is represented by marine sedimentary and volcanic sequences of Cambrian, Silurian, Devonian, Carboniferous, and Permian age. The Cambrian deposits of clayey and oolitic limestone and a basal breccia are exposed only in the foothills southwest of the 
Wu-la-shan. Outcrops of Silurian and Devonian rocks occur north of Pai-yun-o-po and in nearby areas. The principal rock types of Silurian and Devonian age are basalt, andesite, diabase, and tuff; these are intercalated with phyllite and slate in the lower part and with quartzite, phyllite, and sericite schist that contains some clayey crystalline limestone in the upper part (Show and Liu, 1962, p. 384). Lower Carboniferous deposits of conglomerate, conglomeratic sandstone, sandstone, andesitic tuff, limestone, and shale occur only in the northern flank of the Inner Mongolian anteclise, but upper Carboniferous conglomerate, coarse-grained sandstone, sandy shale that contains coal beds, and shale are scattered throughout the Yin-shan Range. These sedimentary rocks were intruded by a variety of plutonic rocks ranging in size from dike to batholith. Alkalic granite, syenite, and some gabbroic rocks are found mainly in the Pai-yun-o-po and $\mathrm{Wu}$-la-shan areas, whereas augite peridotite and dunite were emplaced north, northwest, and northeast of Pai-yun-o-po. Conglomerate, sandstone, and shale of Permian age occur only in the areas northwest and northeast of Pai-yun-o-po. Red beds of Carboniferous and Permian age or Permian and Triassic age, mainly continental facies, are exposed in scattered areas of the Ta-ching-shan. All these rocks unconformably overlie the Precambrian rocks.

The Mesozoic Era is represented by a continental sedimentary sequence of Triassic, Jurassic, and Cretaceous age. Principal rock types are conglomerate, sandstone, mudstone, clay, and shale that contains coal beads; these rocks occur mainly in intermontane basins. During the Tertiary Period, most of the lowlands throughout the Yin-shan Range were covered by a continental sequence of conglomerate, sandstone, mudstone, and clay, locally capped by amygdaloidal olivine basalt. Quaternary alluvial, eolian, and glacial deposits of clay, silt, sand, and gravel are present in lowlands.

\section{STRUCTURE}

The east-west Inner Mongolian anteclise was formed during a largescale deformation at the end of the early Precambrian (Academia Sinica, Institute of Geology, 1959, p. 24). The east-west folds of lower Precambrian beds were subsequently cut by strike-slip faults, in which the movement was generally parallel to the strike of the regional foliation in the gneiss and schist. The deformation was accompanied by granite and pegmatite injection and intense synkinematic migmatization. Foredeeps were formed along the northern flank of the anteclise and later were filled by the Pai-yun-o-po sediments. Prior to the late late Precambrian marine transgression, both broad and over- 
turned east-west folds formed in the Pai-yun-o-po beds, which were then truncated by thrust faults.

After the deposition of the Pai-yun-o-po sediments, this anteclise became more stable, and emerged above sea level to remain a landmass during late Precambrian, Cambrian, and Ordovician times. During an early Paleozoic deformation, there was local subsidence in this area, related to formation of the Mongolian geosyncline to the north. Late Paleozoic deformation involved two major episodes. The first. episode is indicated by the unconformable contact between the Devonian and lower Carboniferous strata, and the second by the unconformity between the upper Carboniferous and Permian beds to the north, northwest, and northeast (Show and Lieu, 1962). Broad to tight and overturned folds formed in the upper Paleozoic beds and were cut by strike-slip faults and thrust faults. These movements were accompanied by the emplacement of alkalic plutonic rocks in the Paiyun-o-po and Wu-la-shan areas and ultrabasic intrusive rocks elsewhere to the north, northwest, and northeast. During that time, many intermontane basins were formed.

Late Mesozoic deformation is clearly indicated by the east-west isoclinal and overturned folds of Paleozoic and Mesozoic strata which were broken by imbricate thrust faults, as indicated in the Ta-chingshan area (fig. 2). During most of the Tertiary, the Yin-shan Range was subject to erosion and denudation accompanied by uplift, and locally it was cut by block faulting; eruption of basalt occurred in late Tertiary time.

\section{ORE DEPOSITS}

\section{OCCURRENCE AND AREAL DISTRIBUTION}

Deposits of rare-element minerals in the Yin-shan Range are found in tabular bodies and irregular bands of iron ore; in pegmatites; and in fluorite, quartz, and carbonate veins. The iron ores are in the Precambrian limestone and dolomite of the Pai-yun-o-po Group in the vicinity of Pai-yun-o-po on the north and in Wu-la-shan on the south. The principal iron ore minerals are magnetite, specularite, and hematite, which are associated with disseminated rare-earth minerals. The most common rare-element-bearing vein deposit is iregular in shape and is generally confined to a north-south belt between Pai-yun-o-po and Wu-la-shan (fig. 2). The vein deposits are concentrated adjacent to the rare-earth-bearing iron ore bodies. The rare-element-bearing pegmatite deposits are in the Precambrian metamorphic complexes of the Sang-kan and Wu-tai Series and are confined to an east-west belt along the southern flank of the Yin-shan Range. This belt extends approximately from the south of Chi-ning on the east to Wu-la-shan 
proper on the west (fig. 2). The distribution pattern of all these types of deposits generally conforms to the regional alinement of the eastwest shear zones.

\section{RARE-EARTH-BEARING IRON ORES}

The Pai-yun-o-po and Wu-la-shan areas are well known for their magnetite-specularite ore deposits. The Pai-yun-o-po area (approx lat $41^{\circ} 44^{\prime}$ N., long $109^{\circ} 52^{\prime}$ E.) is about 90 miles due north of Pao-t'ou (lat $40^{\circ} 36^{\prime} \mathrm{N}$., long $110^{\circ} 03^{\prime}$ E.) in the west Inner Mongolian Autonomous Region. The Wu-la-shan area (approx lat $40^{\circ} 45^{\prime} \mathrm{N}$.; long $109^{\circ} 25^{\prime} \mathrm{E}$.) is about 30 miles N. $70^{\circ} \mathrm{W}$. of Pao-t'ou. The ore deposits of both areas generally are large tabular bodies and blocks that contain lenticular bands and stringers and are in siliceous and cherty limestone in the Pai-yan-o-po area and in dolomite in the Wu-la-shan area. These bodies are in general concordant with the bedding of the carbonate country rocks but in detail have irregular outlines and crosscutting metamorphosed contacts. According to Cheng (1953, p. 127), the ore bodies of the Pai-yun-o-po area are locally in contact with biotite schist. Stratification of the limestone and schistosity of the schist are preserved to some extent in the ore bodies.

Contact metamorphism of the carbonate rocks is generally present, and the calc-silicate hornfels zones are less than 100 meters across. The metamorphosed limestone generally contains quartz-filled cavities and disseminated minerals, including diopside, aegirine-augite, lepidolite, apatite, iron oxides, calcite, quartz, barite, fluorite, epidote, and niobo-aeschynite and other rare-earth minerals. Some of the disseminated minerals are locally replaced by iron ore minerals and fluorite. In the biotite schist, magnetite and fluorite are commonly present.

The principal ore body in the Pai-yun-o-po area is more than 1,000 meters long and several hundred meters wide. The ore mineral is chiefly magnetite in association with hematite, dark-violet fluorite, beiyinite, oborite, aegirine, aeschynite, kataphorite, barite, and cerium-group oxides and other rare-earth minerals. According to Cheng (1953 p. 127), this iron ore contains $40-65$ percent iron, $0.2-1$ percent phosphorus, variable sulfur, and 2-7.2 percent cerium-group oxides. The high-grade iron ore is generally in the central part of the ore body and contains only minor amounts of rare-earth minerals. The low-grade iron ore has a rich rare-earth content, in some parts more than 1.5 percent (elemental). Principal rare-earth elements known to be present are cerium, lanthanum, yttrium, and erbium.

The iron ore bodies of Wu-la-shan were described by Lee (1957). The deposits consist chiefly of magnetite and specular hematite in association with accessory minerals similar to those of the Pai-yun-o-po 
area. Locally apatite, dolomite, pyrite, chalcopyrite, pyrrhotite, galena, sphalerite, and molybdenite are also present. The contact zone between the ore body and dolomite country rock is rather wide and contains as principal disseminated minerals aegirine, aegirine-augite, kataphorite, and albite, in association with niobo-aeschynite and other rare-earth minerals.

\section{FLUORITE, QUARTZ, AND CARBONATE VEINS}

The rare-element-bearing veins are generally in alinement with the east-west shear zones. The veins pinch and swell abruptly, cut across the iron ore bodies, and penetrate the country rock of the Pai-yun-o-po Group. In the Pai-yun-o-po area, the principal fluorite vein is about 1. meter wide and about 500 meters long (Ting, 1933, p. 57). Fluorite is the principal constituent and is associated with very fine grains of magnetite, pyrite, barite, aeschynite, beiyinite, oborite, and parisite (Ho, 1935, p. 279; Wang, T. F., 1958, p. 401). In the Wu-la-shan area additional minerals in the fluorite veins are aegirine, aegirine-augite kataphorite, and albite (Lee, 1957).

The quartz veins generally cut across the slate, quartzite, cherty limestone, and dolomite of the Pai-yun-o-po Group. Quartz and iron oxides form the bulk of the veins; however, veins in carbonate country rock contain mainly quartz, aegirine, aegirine-augite, kataphorite, albite, and oligoclase in association with aeschynite, niobo-aeschynite, calcite, dolomite, phlogopite, biotite, apatite, and barite, and, in places, some pyrite, pyrrhotite, baotite, chalcopyrite, galena, sphalerite, and molybdenite (Chang, 1958, 1962a; Lee, 1957).

The carbonate veins consist chiefly of calcite, iron dolomite, barite, and siderite, and contain a minor amount of thorium-poor monazite, magnetite, and unidentified rare-earth minerals of the cerium and yttrium groups (Chang, 1962b).

\section{PEGMATITES}

The rare-element pegmatites in the Yin-shan Range occur in the Sang-kan and Wu-tai metamorphic complexes of biotite granitoid gneiss, hornblende gneiss, garnet gneiss, mica schist, and equigranular to porphyritic granites. Structural discordance of pegmatites and country rock is characteristic. Although the pegmatites generally follow east-west structural alinement, locally they deflect toward the northwest and the northeast. The dip angles of pegmatites are generally over $70^{\circ}$ and in places are vertical. Pegmatites in the gneisses and schists have generally sharp contacts with country rock, whereas those in the granites have gradational contacts. The known exposed width of pegmatites ranges from 1 to 6 feet (Sun, 1934, p. 76). Three principal rare-element-bearing types are recognized in this belt (Kuo, 1957, 
1958a) : (a) biotite pegmatite, (b) muscovite pegmatite, and (c) biotite-muscovite pegmatite. The first two types are generally abundant and widely distributed; they may be associated with aplite dikes and cut by Tertiary diabase dikes. The biotite-muscovite pegmatites, found locally between the other types, are transitional.

The bulk mineralogical composition of the biotite pegmatites consists of microcline, perthite, quartz, biotite, allanite, magnetite, and fergusonite, in association with some hematite, specularite, martite, yinshanite, amazonite, muscovite, epidote, apatite, pyrite, limonite, kaolinite, calcite, manganese oxides, samarskite, euxenite, sinicite, ampangabeite, monazite, zircon, titanite, thorite, uranothorite, and bröggerite (uraninite). The most common minerals of the muscovite pegmatites are microcline, perthite, plagioclase, kaolinite, quartz, muscovite, cleavelandite, black tourmaline, garnet, topaz, and beryl, in association with accessory biotite, chalcedony, epidote, apatite, fluorite, cassiterite, magnetite, hematite, martite, specularite, tysonite, pyrite, limonite, calcite, jiningite, manganese oxides, samarskite, sphene, ilmenorutile, monazite, columbite, yttrotantalite, chrysoberyl, toddite, spodumene, killinite, lepidolite, lithium tourmaline, tantalian aeschynite, and variscite. The biotite-muscovite pegmatites consist chiefly of microcline, perthite, quartz, biotite, and muscovite, in association with plagioclase, cleavelandite, amazonite, topaz, garnet, black tourmaline, epidote, fluorite, magnetite, hematite, specularite, columbite, martite, pyrite, limonite, kaolinite, calcite, manganese oxides, samarskite, fergusonite, sinicite, monazite, zircon, toddite, sphene, ilmenorutile, xenotime, thorite, bröggerite, beryl, ferrithorite, and uranothorite. Characteristic minerals of these three types of pegmatite are allanite, zircon, euxenite, uranothorite, and ampangabeite for the biotite type; chrysoberyl, spodumene, lepidolite, lithium tourmaline, variscite, columbite, yttrotantalite, and cassiterite for the muscovite type; and xenotime, ferrithorite, thorite, uranothorite, and intergrown sinicite and beryl for the biotite-muscovite type.

The internal structure of the pegmatites consists of units of contrasting mineralogy or texture or both. Such units for pegmatites in general have been classified as zones, replacement units, and fracturefilling units (Cameron and others, 1949). Zonal distribution in the three pegmatite types under discussion was given by Kuo $(1957,1958 \mathrm{a})$ and Sze (1957), but detailed information concerning the mineral sequence and structural position of the border, intermediate, and wall zones in each pegmatite type is generally lacking. When Kuo and Chung (1957a) investigated the toddite deposits in the Inner Mongolian Autonomous Region, they described the zonal distribution in the muscovite type of pegmatite: coarse-grained potassium feldspars 
are the principal minerals of the border and wall zones; muscovite is the common mineral of the intermediate zone; and blocky quartz is the chief constituent of the core. The blocky quartz zone occupies about one-fourth to one-third of the total thickness of the muscovite pegmatite, locally as much as half of the thickness. Toddite is present generally in the potassium feldspar zone. The country rocks are commonly mineralized with garnet. According to Kuo (1958a, p. 93), the highest concentrations of zirconium, hafnium, titanium, uranium, thorium, niobium, and some beryllium occur in the potassium feldspar zone or at the contact between the potassium feldspar zone and the blocky quartz zone in all three types of pegmatites.

Irregular to lenticular bodies of replacement units occur only in the muscovite type of pegmatite (Kuo, 1958a, p. 94). Principal minerals in these replacement units are albite, muscovite, lepidolite, beryl, lithium tourmaline, and cassiterite. As compared with the biotite and biotite-muscovite pegmatites, the muscovite type has a higher content of beryllium, lithium, cesium, niobium, tantalum, and tin and a lower content of uranium, thorium, titanium, zirconium, and hafnium.

Tabular or veinlike bodies fill fractures in the preexisting pegmatites. These units are locally associated with spherical cavities which vary from 2 to 3 feet across (Sun, 1934). The cavities are commonly partly filled with red or yellowish-red clay in which smoky quartz with attached greenish-blue beryl or topaz is embedded. Principal minerals of the fracture-filling units are quartz, biotite, and muscovite.

The areal distribution of these three types of pegmatites in relation to the granite intrusive bodies was further defined by Kuo (1958a, p. 95). The biotite type occurs generally near the granite body and contains abundant allanite as well as zircon, monazite, samarskite, and euxenite, all found chiefly in parts of the pegmatites rich in potassium feldspar. Allanite is less common in biotite pegmatites farthest from the granite. Biotite-muscovite pegmatite containing beryl lies outside the zone of biotite pegmatites that contain yttrotitanite and chrysoberyl. Locally the zircon-or samarskite-bearing biotite type is in direct, contact with the muscovite type, in which the blocky quartz zone is well formed and beryl is the characteristic rare-element mineral.

\section{MINERALOGY}

Most of the known minerals in the deposits of the Yin-shan Range are typical of magnetite ore deposits, fluoride-oxide and sulfide-carbonate veins, and pegmatites. Magnetite, specularite, and hematite are abundant in the iron ores. Fluorite, quartz, calcite, dolomite, aegirine, kataphorite, albite, and oligoclase are the principal constituents of the veins. Microcline, perthite, quartz, biotite, muscovite, beryl, and 
other silicates are characteristic minerals of the pegmatites. The rareelement minerals in all these deposits are chiefly aeschynite, allanite, ampangabeite, apatite, baotite, beiyinite, beryl, bröggerite, chrysoberyl, columbite, euxenite, fergusonite, fluorite, ferrithorite, jiningite, monazite, niobo-aeschynite, oborite, parisite, samarskite, sinicite, tantalian aeschynite, thorite, sphene, ilmenorutile, tysonite, toddite, uranothorite, xenotime, yinshanite, yttrotantalite, and zircon. Other minor constituents are aegirine-augite, amazonite, barite, black tourmaline, cleavelandite, cassiterite, chalcedony, chalcopyrite, diopside, epidote, galena, garnet, hornblende, kaolinite, killinite, lepidolite, lithium tourmaline, limonite, manganese oxides, martite, molybdenite, plagioclase, pyrite, pyrrhotite, phlogopite, sphalerite, siderite, spodumene, topaz, and variscite.

\section{MINERALIZATION}

The rare-element mineral deposits in the Yin-shan Range were formed in two principal periods of mineralization, accompanied by large-scale tectonic deformation. The first period is represented by the emplacement of rare-element-bearing pegmatites in the Precambrian metamorphic rocks at about the end of early Precambrian time and before deposition of the Pai-yun-o-po Group (Kuo and others, 1957, and $\mathrm{Li}, \mathrm{Pu}, 1965, \mathrm{p} .1664)$. The second period is indicated by radiometric ages to have occurred approximately in late paleozoic time $(\mathrm{Li}$, $\mathrm{Pu}, 1965, \mathrm{p} .1668$ ). During that period, synkinematic emplacement of large masses of rare-earth-bearing iron ores in the Pai-yun-o-po limestone and dolomite and in Precambrian schists was brought about by high-temperature alkalic solutions. This metasomatism was followed by fissure fillings of rare-element-bearing fluorite, quartz, and carbonate minerals. The sequence of mineralization in each principal period is very complex, as shown by the spatial relations of minerals and by the structural relations among iron ore bodies, veins, and various types of pegmatites. Generally speaking, the paragenesis of the rare-element minerals indicates simultaneous deposition, replacement, and alteration of mineral species.

The alkalic carbonate- and iron-rich solutions from which the iron and rare-element minerals were precipitated by oxidation are genetically related to the alkalic granites, syenite, and gabbroic rocks throughout the mineralized belt (fig. 2). The solutions contained much lanthanum, cerium, niobium, fluorine, sodium, and phosphorus. The sequence of the mineral-forming process is tentatively believed to be as follows:

1. Large-scale deposition of iron ore minerals with simultaneous infiltration-diffusion replacement of the carbonate country rocks to form diopside, aegirine-augite, apatite, and lepidolite. 
2. Wholesale chemical reaction with country rock and main ore bodies by rather mobile alkalic carbonate and iron fluids that contained much sulfur and silicon, causing partial or, more likely, complete replacement of pyroxenes and apatite by magnetite and fluorite in the contact-metamorphic zone between the carbonate country rock and iron ore bodies; the formation of vugs (Holland and Borcsik, 1965 , p. 368); and further enrichment of rare-earth deposits in the iron ore bodies, accompanied by fluorite mineralization elsewhere and locally by deposition of pyrrhotite, magnetite, pyrite, chalcopyrite, and other sulfide minerals.

3. Fissure fillings precipitated from a residual alkalic carbonate and iron solution, which transported substantial amounts of silicon, calcium, phosphorus, magnesium, and aluminum to produce quartz-aeschynite veins; and subsequently, formation of carbonate veins.

The pegmatites are genetically related to the late-stage magmatic differentiation of the nearby Precambrian granite instrusive bodies. The paragenesis of rare-element minerals of these pegmatites is given by Kuo $(1958$ a, p. 93) : allanite and monazite $\rightarrow$ zircon $\rightarrow$ fergusonite $\rightarrow$ samarskite $\rightarrow$ euxenite $\rightarrow$ xenotime $\rightarrow$ yttrotantalite $\rightarrow$ columbite $\rightarrow$ tantalite $\rightarrow$ sinicite $\rightarrow$ beryl $\rightarrow$ spodumene $\rightarrow$ lithium tourmaline $\rightarrow$ beryl (second generation) $\rightarrow$ lepidolite. As to the time and space relations of mineralization, variation in mineral sequences occurred in each type of pegmatite, but monazite deposition was generally concentrated in an early stage of mineralization and persisted throughout the sequences. Allanite, zircon, and samarskite are the relatively high-temperature minerals of the biotite pegmatites. The intermediate-temperature minerals are sinicite and beryl, which characterize the biotite-muscovite pegmatites. Lepidolite, lithium tourmaline, and beryl are the low-temperature minerals of the muscovite pegmatites. Most of the rare-element minerals are concentrated in the potassium feldspar zones or in the contact between the potassium feldspar and quartz zones in all the pegmatite types.

\section{NAN-LING RANGE}

\section{REGIONAL GEOLOGY}

The Nan-ling Range (figs. 1,3) forms an east-west divide in south China, separating the Yangtze drainage system on the north from the Chu-chiang system on the south. The range includes primarily the mountains and hills between north Kwangtung and southeast Hunan but also includes the Chu-kwang-shan and Kwang-young-shan in east Hunan and west Kiangsi and the Ta-yu-ling and Chiu-lien-shan in south Kiangsi and north Kwangtung. The Chiu-lien-shan is the 


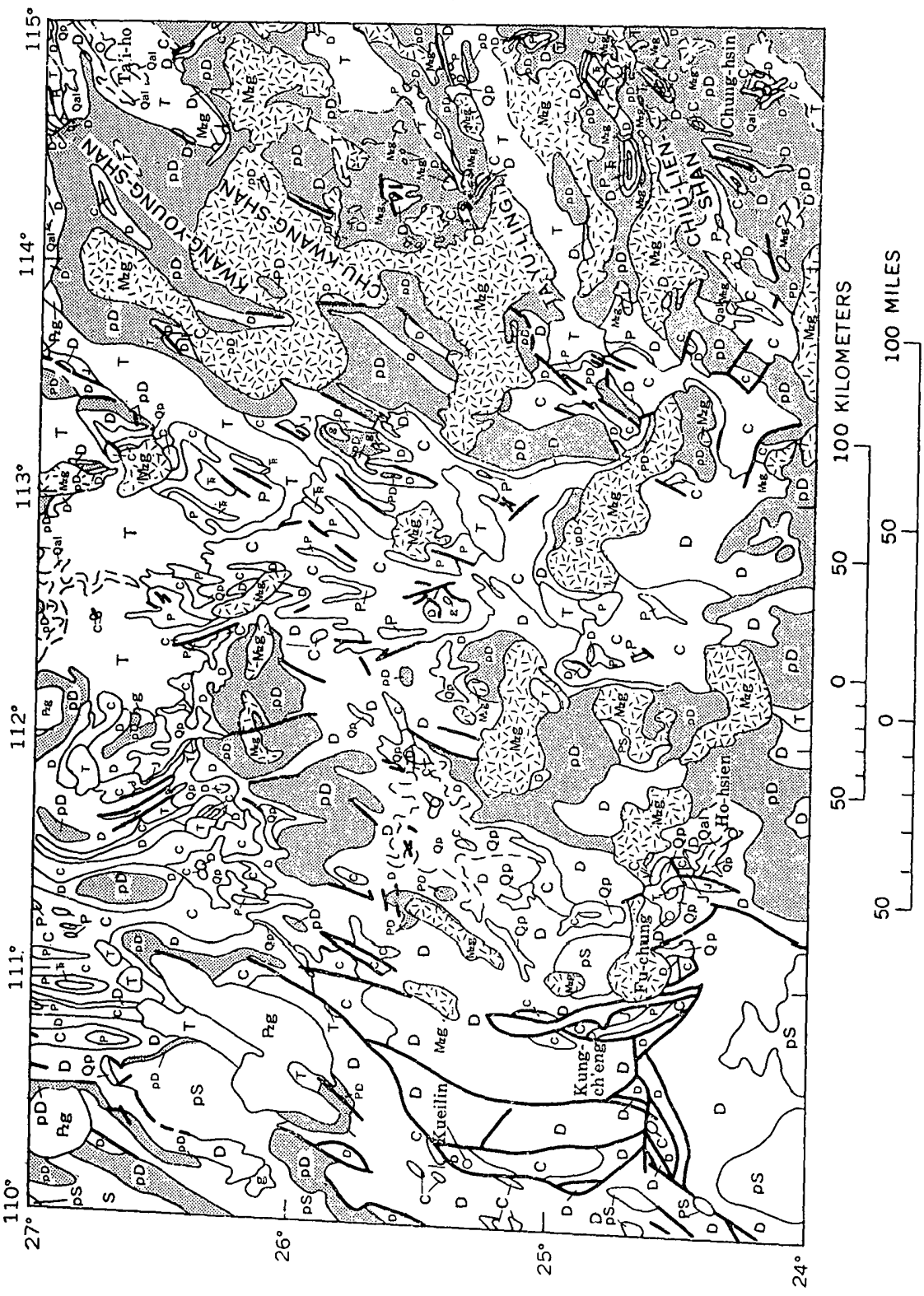




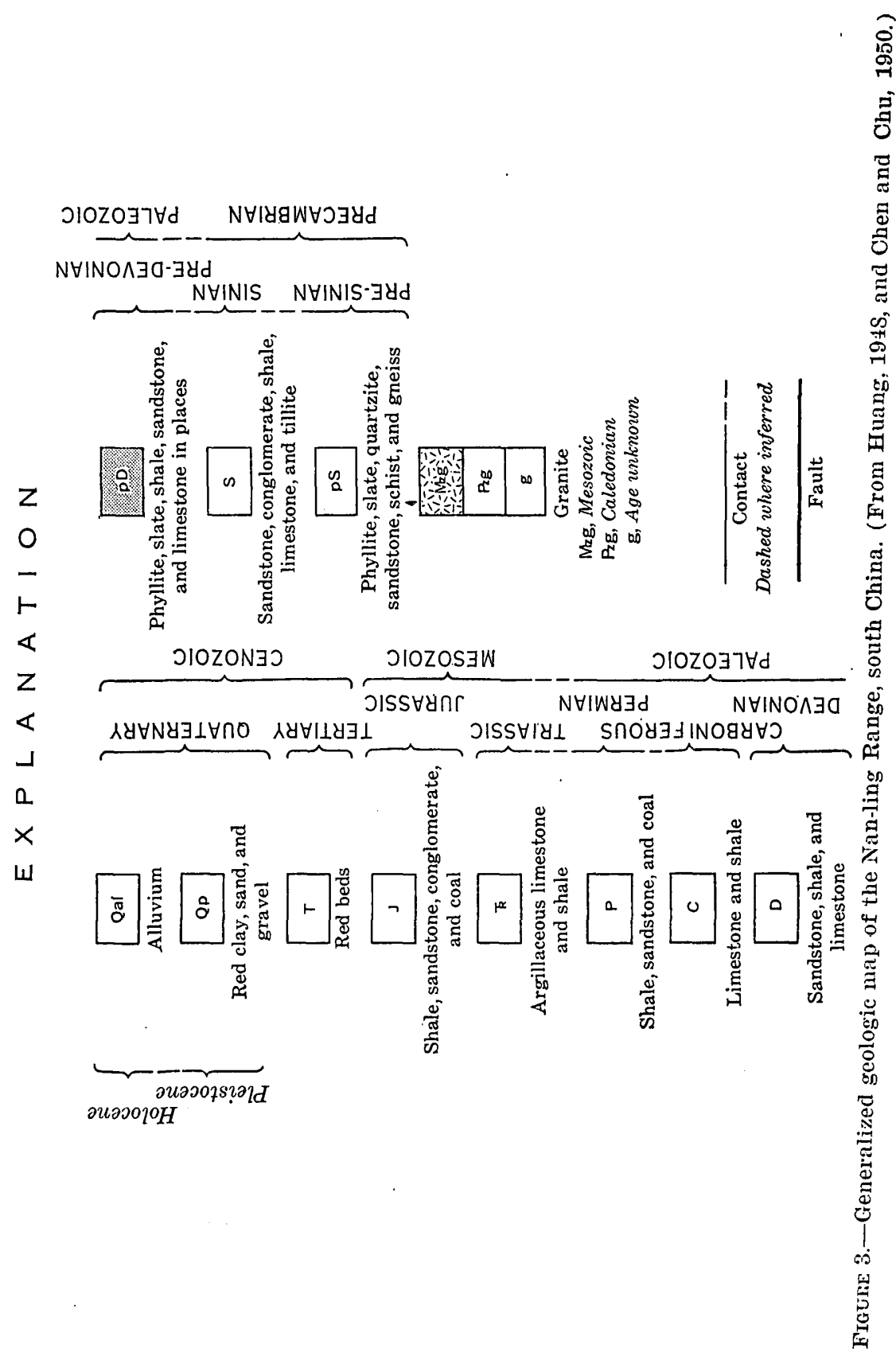


easternmost extension of the Nan-ling mountain chain, and it deflects toward the northeast to join the $\mathrm{Wu}$-yi-shan in east Kiangsi and west Fukien. Altitudes range from 1,270 to 1,900 meters.

The mountains are structurally a part of the Cathaysian anteclise (Academia Sinica, Institute of Geology, 1959, p. 56). The basement rocks are generally well exposed in the Nan-ling proper and consist of pre-Sinian slightly metamorphosed rocks. Sinian (upper Precambrian) rocks are found in scattered areas in the southwest part of the Nan-ling Range. A continental sequence of lower Paleozoic rocks and a marine sequence of upper Paleozoic rocks are widely distributed and unconformably overlie the pre-Sinian metamorphic rocks. These sedimentary rocks are locally penetrated by Caledonian biotite granites. Most hilly and lowland areas are covered by marine Triassic limestone and shale as well as a continental sequence of Jurassic to Tertiary clay, shale, sandstone, and in places coal beds. A large-scale orogenic movement took place during late Mesozoic time, when most of the older rocks were folded and faulted and granite intrusion was widespread. Quaternary alluvial red clay, sand, and gravel conceal the bedrock in some of the lowland areas. The generally broad but locally overturned folds of these older rocks were cut through by many northeast-trending normal faults and north- or northeast-trending thrust faults.

\section{STRATIGRAPHY}

The exposed basement rocks are pre-Sinian flysch-metasedimentary rocks-phyllite, slate, quartzite, sandstone, mica schists, and gneiss in south Kiangsi, east and north Kwangsi Chuang Autonomous Region, and south Hunan (Academia Sinica, Institute of Geology, 1959 , p. 56). The thickness of these rocks ranges from 1,000 to 2,000 meters. The Sinian rocks occur only in north Kwangsi Chuang Autonomous Region and southwest Hunan of the southwest Nan-ling Range. They consist of sandstone, tuffaceous sandstone, and conglomerate in the lower part; and cherty limestone, shale, and locally tillite in the upper part. Thickness ranges from 100 to 600 meters.

Paleozoic rocks are widely distributed throughout the Nan-ling Range and are represented by continental and marine sedimentary sequences of Cambrian through Permian age. Pre-Devonian rocks exposed in south Kiangsi are principally phyllite, slate, quartzose sandstone, and phyllitic shale, having a total thickness of about 2,000 meters. Micaceous sandstone and shale, 300 meters thick, are found in east Kwangsi Chuang Autonomous Region. Phyllite, slate, sandstone, and shale, more than 2,000 meters thick, are exposed in south Hunan. The pre-Devonian rocks exposed in north Kwangsi Chuang Autonomous Region are represented by Cambrian and Ordovician carbona- 
ceous and sandy shales in the lower part, and cherty and thick-bedded limestone with interbeds of shale and sandstone in the upper part; total thickness is about 1,800 meters.

Devonian rocks are sandstone and shale in the lower part and cherty, thin- to thick-bedded limestone with interbeds of shale in the upper part. Thickness ranges from 20 meters in south Kiangsi to more than 1,000 meters in north and east Kwangsi Chuang Autonomous Region and south Hunan. Carboniferous and Permian rocks are widespread in the northwest and southwest Nan-ling Range. They consist of shale and sandstone with coal beds in the lower part and cherty, bituminous, thick-bedded to massive, crystalline limestone in the middle part, which grades into shale and sandstone with coal beds in the upper part. Thickness of this sequence is as much as 1,400 meters. The permian rocks are generally sparse in the north Kwangsi Chuang Autonomous Region, whereas the Carboniferous sequence of limestone and shale attains a thickness of more than 1,200 meters in this area.

The Mesozoic rocks are represented by a Triassic marine sedimentary sequence and a Jurassic and Cretaceous continental sedimentary sequence. The Triassic rocks occur only in south Kiangsi, south Hunan, and east Kwangsi Chuang Autonomous Region and consist of thinbedded clayey dense limestone with interbeds of shale. Thickness ranges from 40 to 300 meters. The Jurassic rocks are exposed in the same general areas, and consist of shale, sandstone, and conglomerate with coal seams. Thickness ranges from 300 to 600 meters. Cretaceous rocks crop out only in south Kiangsi, adjacent to the northeast part of the range, where they attain a thickness of about 1,000 meters. Principal rock types are conglomerate, sandstone, quartzite, phyllite, shale, tuffaceous sandstone, and, in places, rhyolite flows.

Most lowlands throughout the Nan-ling Range are covered by a Tertiary continental sequence of red beds, which consists chiefly of variegated shale, clay, sandstone, basal gravel, and locally breccia. Quaternary alluvial red clay, sand, and gravel are well formed along stream valleys.

\section{STRUCTURE}

The Nan-ling Cathaysian anteclise was formed during several periods of tectonic deformation from late Precambrian to early Paleozoic time and became stable at about the close of the Caledonian deformation. The northeast-trending tight folds of pre-Sinian beds were locally intruded by a titanium-bearing biotite-muscovite granite. The absence of Sinian sedimentary rocks in most of the Nan-ling Range indicates emergence during this time, but large-scale subsidence and deposition of early Paleozoic sediments followed. During Caledonian deformation, the early Paleozoic rocks underwent tight folding accom- 
panied by marked subsidence in the northwest and southwest Nanling Range and by granite intrusion elsewhere. Peneplanation throughout south China preceded the deposition of Devonian rocks. The Hercynian deformation involved chiefly epeirogenic movements, as indicated by the nature of the sedimentary sequence as well as by the discomformable contacts in the late Paleozoic sedimentary rocks.

Early Mesozoic deformation is locally marked by unconformable contact of Upper Triassic and Lower Jurassic rocks and by biotite granite. Effects of the late Mesozoic orogenic movement are very conspicuous throughout the Nan-ling Range; the orogeny is clearly indicated by the north- or northeast-trending, locally overturned folds of Paleozoic and Mesozoic beds and by widespread volcanic activity and large-scale granite intrusions. These folds were severely truncated by north-trending normal and blockfaults and northeast-trending thrust faults. As a result, composite joint systems were formed that have east, north-northwest, and north-northeast trends. The easttrending joint set is generally well formed and played a major role in ore mineralization. Tension joints are more abundant than shear joints. During most of the Tertiary, the Nan-ling Range was subjected to erosion and denudation, accompanied by local uplifting and block faultings. Basalt eruption occurred only along the coastal areas.

\section{ORE DEPOSITS}

\section{OCCURRENCE AND AREAL DISTRIBUTION}

Rare-element minerals in the Nan-ling Range occur in fissure-filling tungsten-quartz veins, in pegmatites, in tin-bearing placers, and as disseminated grains in granodiorite. Of these, the tungsten-quartz veins are widely distributed and form a mineralized belt that extends approximately from Chung-hsin (lat $24^{\circ} 13^{\prime} \mathrm{N}$.; long $114^{\circ} 44^{\prime} \mathrm{E}$.), north Kwangtung, on the south, to the vicinity of Ta'i-o (lat $26^{\circ} 48^{\prime} \mathrm{N}$., long $114^{\circ} 56^{\prime} \mathrm{E}$.), south Kiangsi, on the north. Pegmatites are of the muscovite variety and are sporadically present. The tin-bearing placers are confined to a belt that extends approximately from Fu-chung (Chung-shan; lat $24^{\circ} 32^{\prime} \mathrm{N}$., long $111^{\circ} 18^{\prime} \mathrm{E}$.) on the north to Ho-hsien (lat $24^{\circ} 20^{\prime} \mathrm{N}$., long $111^{\circ} 39^{\prime} \mathrm{E}$.) on the south, northeast Kwangsi Chuang Autonomous Region. The disseminated-grain deposit is probably in a granodiorite intrusive body, about 10 miles S. $47^{\circ} \mathrm{E}$. of Kungch'eng (lat $24^{\circ} 50^{\prime} \mathrm{N}$., long $110^{\circ} 49^{\prime} \mathrm{E}$.), northeast Kwangsi Chuang Autonomous Region. The distribution pattern of the tungsten-quartz veins conforms closely to the regional alinement of shear and tensionjoint zones. 


\section{TUNGSTEN-QUARTZ VEINS}

These veins consist of hypothermal and less productive hydrothermal varieties (Hsü and Ting, 1943). The hypothermal veins are welldefined tabular bodies that fill preexisting fissures in granite or in the pre-Devonian metasedimentary rocks near the granite. They are generally regular in strike and dip; major trends are east and northeast. Zonal arrangement of the ore minerals is common. In any one of these veins, wolframite occupies a lower zone that the bismuth minerals and a higher zone than molybdenite; arsenopyrite is dominant in places, and cassiterite seems to be richer in the upper zone. Maximum width of the veins is 3.5 meters, but most of the productive veins range from 0.1 to 0.5 meters in width. Lateral and vertical variation in width is common, but as a rule the wide veins maintain their width for long distances. Branching is not common and generally does not obscure the apparent regularity of the veins. Most veins are a hundred to several hundred meters long; only a few are several meters to tens of meters long. The vertical extent of veins in sedimentary rocks generally is greater than that of veins in granite. Principal minerals are wolframite, scheelite, cassiterite, molybdenite, bismuthinite, stibnite, and quartz, in association with tungstite, fluorite, topaz, lepidolite, microcline, specularite, rutile, hematite, zinnwaldite, calcite, zircon, bismite, molybdite, sphalerite, pyrrhotite, native bismuth, beryl, monazite, biotite, bismutite, smithsonite, psilomelane, xenotime, pyrolusite, chlorite, zeolite, uraninite, and thortveitite and other rare=element minerals.

Hydrothermal replacement veins are generally associated with zones of greisen in the form of irregular patches, lenses, pockets, and rudely tabular bodies in greisenized granites in the upper part of granite cupolas. The width of the greisenized zone is nowhere more than 3 meters and mostly less than 1 meter $(\mathrm{Wu}, 1957)$. Zonal distribution in these veins is indicated by both lateral and vertical changes in mineral assemblages in the greisenized granite at Ta-yu-ling ( Wu, 1957; $\mathrm{Tu}$ and Liu, 1965, p. 266). A quartz zone is the core of the vein and is followed successively by a muscovite zone, muscovite-quartz zone, mica-enriched greisen zone, quartz-enriched greisen zone, and alkalifeldspar-enriched granite. The main body of the vein includes the quartz zone through the muscovite-quartz zone with its vugs, and contains potassium feldspar, carbonates, cassiterite, beryl, wolframite, and sulfides. The veins are widest in the middle parts and become narrower both upward and downward. In the upper parts, the most common minerals are cassiterite, beryl, molybdenite, micas, topaz, and quartz that has comb structure. The middle parts are characterized by more 
abundant potassium feldspar, carbonate minerals, helvite, wolframite, and quartz; vugs are larger. The lower parts are marked by the appearance of abundant sulfide and carbonate minerals. Principal minerals of these replacement veins are lepidolite, muscovite, potassium feldspar, quartz, tourmaline, topaz, and fluorite, in association with beryl, helvite, magnetite, xenotime, titanite, pyrite, spinel, chalcopyrite, stibnite, arsenopyrite, protolithionite, epidote, cassiterite, wolframite, molybdenite, and, in places, apatite.

\section{PEGMATITES}

The pegmatites consist predominantly of the muscovite variety, and are irregular dikes and pockets in small granite intrusions or in marginal parts of batholiths. The most common minerals are orthoclase or microcline, quartz, muscovite, lepidolite, tourmaline, fluorite, and topaz, in association with wolframite or scheelite, garnet, cassiterite. molybdenite, and minerals of uranium, thorium, and beryllium.

\section{DISSEMINATED GRAINS IN GRANODIORITE}

This type of deposit occurs in a Triassic granodiorite body in the southwest Nan-ling Range, northeast Kwangsi Chuang Autonomous Region. The granodiorite is in metamorphosed contact with the Devonian marine Tung-kung-ling limestone and Hsiao-shan sandstone, which are unconformably overlain by the Jurassic continental sequence of shale and sandstone with coal beds and fergusonite-bearing basal conglomerate. Study of this conglomerate led to discovery of the fergusonite granodiorite (Wang, T. F., 1964). The granodiorite body has a fergusonite-rich marginal zone that contains fluorite, perthite, anorthoclase, and plagioclase of high $\mathrm{Ab}$ content; pegmatitic masses generally appear within this zone. The intermediate or transitional zone is characterized by abundant monazite. The inner zone is rather porphyritic and contains perthite and abundant sphene. Principal rock-forming minerals are perthite, anorthoclase, orthoclase, albite, oligoclase, quartz, biotite, and fergusonite, in association with sphene, fluorite, magnetite, zircon, allanite, monazite, xenotime, thorite, and apatite. Oligoclase and biotite are commonly replaced by fergusonite; in the marginal zone, oligoclase is replaced in part by fluorite, quartz, and fergusonite.

\section{TIN-BEARING PLACERS}

The tin-bearing placers were formed as valley fill and extend northnorthwest to south-southeast for about 24 miles in northwest Kwangsi Chuang Autonomous Region. The older alluvial tin-bearing deposits of red clay, sand, and gravel form high terraces generally 30 to 40 meters, locally more than 100 meters, above the river bed (Hsieh, 1943, 
p. 81-82). These deposits are locally 70 or more meters thick. The more recent alluvial deposits of tin-bearing sand and gravel form lower terraces 20 to 50 meters above the river bed and range in thickness from 10 to 40 meters. Alluvial fans extend to 100 or 200 meters above the river; these well-stratified deposits are the principal source of the placers that yield rare-element minerals. The placers are of the cave and fissure types in limestone terrain. Most of the ore-mineral concentrates occur in the lower part of the placers where the principal ore minerals are cassiterite and stannite in association locally with phosphuranylite, uraninite, and monazite ( $N$ an and $\mathrm{Wu}, 1944)$. These minerals were apparently derived from the granites to the north.

\section{MINERALIZATION}

The tungsten-quartz veins and pegmatites are genetically related to the granite intrusions throughout the Nan-ling Range, particularly the late Mesozoic granites. These granite stocks generally contain 30 to 46 percent potassium, 13 to 30 percent plagioclase $\left(\mathrm{An}_{6-10}\right), 30$ to 38 percent quartz, and a trace to 12 percent biotite and muscovite. Accessory minerals include garnet, zircon, rutile, magnetite, apatite, allanite, and monazite (Hsü and others, 1963, p. 20-23). Greisenization, muscovite enrichment, albitization, and dissemination of fluorite characterize the hydrothermal alteration of these granites. Principal oreforming elements of these late Mesozoic granites are W, Sn, Mo, Bi, $\mathrm{Li}, \mathrm{Be}, \mathrm{Sr}, \mathrm{Pb}, \mathrm{Ga}, \mathrm{Zr}, \mathrm{Ti}, \mathrm{Sb}, \mathrm{Zn}, \mathrm{Cu}, \mathrm{La}, \mathrm{Y}, \mathrm{Yb}, \mathrm{Nb}$, and U. The major phase of mineralization took place in the Early Cretaceous during the second phase of late Mesozoic deformation. It resulted in enrichment of tungsten, tin, lead, zinc, and antimony, in association with rare-element metals. Hsü, Sun, Wang, and Hu (1963) stated that the wolframite-quartz veins were formed under hypothermal conditions and were followed by the formation of mesothermal scheelite-wolframite-quartz veins and epithermal stibnite-wolframite-quartz veins or scheelite-fluorite-calcite-quartz veins. The mesothermal and epithermal sequences of mineralization were generally accompanied by hydrothermal alteration. Later, Tu and Liu (1965, p. 263) confirmed Hsü's observation and mentioned that some late Mesozoic granites have a much higher content of tungsten, bismuth, mobybdenum, and tin than the early Mesozoic granites. These authors believed that vertical zoning of wolframite deposits in replacement veins of the granites was the result of metasomatic interaction between polyascendant mineralizer solutions and minerals of the granitic wallrock. Deposition of sulfide minerals (including molybdenite) preceded that of wolframite and helvite, and these were followed by deposition of cassiterite, beryl, and late molybdenite. 
The disseminated type of rare-earth mineral deposit in Triassic granodiorite was formed by magmatic fractionation. Owing to the presence of pegmatitic masses and the spatial relation of mineral grains in the marginal zone, it is believed that these deposits, which contain an anomalous concentration of uranium and thorium minerals, were formed during the late stage of magmatic differentiation.

\section{SIMILAR AREAS OF RARE-ELEMENT MINERAL DEPOSITS}

Several other areas of rare-element mineral deposits (fig. 1) are postulated by the author on the basis of regional geology described in the literature. Areas of fissure-filling or replacement carbonate veins, pegmatites, and disseminated grains in alkalic granite will be discussed. Fissure-filling carbonate veins occur in the vicinity of Feng-huang in Hunan Province and Tzu-chin-shan, Hu-yeh-shan, Lin-hsien-Hsing-tai, and P'ing-yang in Shansi Province. Areas of pegmatites are at Hai-chéng in Liaoning Province and in the Altai Mountains of the Sinkiang Uighur Autonomous Region. The disseminated type is represented by the $\mathrm{K}$ wang-hai niobium-bearing granite in Kwangtung Province. Scanty information is available on rareelement minerals in iron ores, fissure-filling veins, and placers on Hainan Island, and in Tertiary gravel beds and Quaternary lacustrine deposits in the Sinkiang Uighur Autonomous Region. Both areas, however, have yielded a large amount of uranium and thorium ores in the past (Li, Yang, 1967, p. 1-2).

\section{AREAS OF FISSURE-FILLING OR REPLACEMENT CARBONATE VEINS}

\section{FENG-HUANG}

The area of rare-element minerals deposits extends from the vicinity of Feng-huang, Hunan Province (lat $27^{\circ} 54^{\prime}$ N., long $109^{\circ} 36^{\prime}$. E.), southwestward for a considerable distance. A northeast-trending fold system involves rocks of Sinian and Cambrian age. The Sinian rocks are represented by calcareous shale with interbeds of clayey limestone in the lower part and thin-bedded and cherty limestone in the upper part. This sequence grades upward into Lower Cambrian shale and limestone. These strata are overlain by Upper Cambrian thick-bedded limestone with interbeds of calcareous shale. Broad to tight folds in these strata are cut by a northeast-trending fracture system and were penetrated by an alkalic igneous complex probably during Caldedonian deformation. This igneous complex consists of stocks of nepheline syenite, urtite, aegirine-augite syenite, and biotite-augite syenite. Dikes are made up principally of urtite, which is coarse grained and consists chiefly of euhedral brick-red nepheline, black melanite, and lesser amounts of aegirine, orthoclase, fenghuangite, and sphene (Peng and 
Lieu, 1962, p. 677). Nepheline is largely sericitized and has a hematite coating; orthoclase is generally fresh.

The rare-element-bearing carbonate-silicate veins, quartz veins, and some alkalic dikes are found in Cambrian limestone and are locally associated with metasomatic replacement zones. The contact-metamorphic zone, which is more than 10 meters wide in places, contains disseminated diopside, vesuvianite, melanite, biotite, lepidolite, epidote, allanite, zircon, sphene, and apatite (Peng, 1959). Many veinlets of aegirine-augite, potassium feldspars, and melanite are present and, in places, contains as much as 0.612 percent $\mathrm{Nb}_{2} \mathrm{O}_{5}, 1.61$ percent $\mathrm{ZrO}_{2}$, and 0.22 percent rare-earth oxides. The carbonate-silicate veins were emplaced in the composite fractures of Cambrian limestone, which are generally in alinement with the northeast tectonic trend. The veins are nearly vertical and are 1 to several meters wide. Mylonitization and brecciation have occurred locally within the veins. The bulk composition of these veins includes potassium feldspar, albite, strontium calcite, thorite, and thorogummite. Associated minerals include manganese spar, sphene, rutile, hematite, quartz, biotite, lepidolite, sericite, chlorite, augite, melanite, pyrite, galena, and limonite. The rareelement-bearing quartz veins consist chiefly of thorite, thorogummite, and quartz in association with minerals of cerium and lanthanum earths. The rare-element-bearing urtite dikes occur chiefly in nepheline syenite. The urtite consists chiefly of nepheline and melanite with accessory minerals of aegirine, orthoclase, fenghuangite, and sphene.

These deposits are genetically related to the alkalic igneous complex. It is believed that the sequence of mineralization was the formation of silicate minerals during the early phase of alkalic magma fractionation followed by carbonatization and rare-earth mineralization through intense infiltration and diffusion by residual alkalic magma fluids.

TZU-CHIN-SHAN, HU-YEH-SHAN, P'ING-YANG, AND LIN-HSIEN-HSING-TAI

Tzu-chin-shan (approx. lat $38^{\circ} 10^{\prime} \mathrm{N}$., long $110^{\circ} 58^{\prime}$ E.) (Wang, C. C., 1947) is 100 miles $\mathrm{N}$. $75^{\circ} \mathrm{W}$. of Tai-yuan in the northeastern part of the Shensi-Shansi loess uplands. An alkalic igneous complex and Mesozoic clastic rocks form broad anticlines cut by north-trending graben faults. The five principal rare-element-bearing rock groups, from youngest to oldest, are: tinguaite dike, brecciated syenite volcanic neck, nepheline syenite, augite syenite, and trachyandesite. The tinguaite dikes consist chiefly of sanidine, orthoclase, nepheline, alkalic pyroxene, and amphibole; they cut across older rocks in alinement with northwest- and northeast-trending fracture systems. The syenite volcanic neck, in the central part of the area, is intensely brecciated, and the broken blocks are cemented by vesicular sanidine trachyte and 
other alkalic rocks. The nepheline syenite occurs as scattered dikes and stocks in augite syenite and consists of sanidine, orthoclase, anorthoclase, nepheline, aegirine, and biotite. The augite syenite forms laccoliths that cover a large part of the area; it consists chiefly of oligoclase, albite, anorthoclase, barkevikite, and aegrine-augite. The augite syenite was locally brecciated, and lamprophyric rocks cement the breccias. The trachyandesite, which covers most of the area, contains andesine $\left(\mathbf{A b}_{56}, \mathbf{A n}_{44}\right)$, hornblende, diopside-augite, and some anorthoclase and orthoclase (Wang, C.C. 1947, p. 233-234). These alkalic rocks were derived from an akeritic magma (Nyström, 1947, p. 91).

$\mathrm{Hu}$-yeh-shan (lat $38^{\circ} 00^{\prime} \mathrm{N}$., long $111^{\circ} 58^{\prime} \mathrm{E}$.) is about 40 miles due west of Tai-yuan in central Shansi Province. A southeast-trending anticline is cut by a northeast-trending fracture system. The folded strata consist of Sinian cherty limestone, slate, and quartzite, Cambrian and Ordovician limestone, a Carboniferous coal series with interbeds of limestone, and Permian sandstone and shale. An alkalic igneous complex in laccoliths, stocks, and volcanic necks cuts the Ordovician limestone and was formed in two distinct sequences (Nyström, 1947, p. 86-87). The early sequence is represented by the akerite intrusion. This rock is medium grained and consists of orthoclase, andesine, oligoclase, albite, hornblende, diopside, and accessory minerals of sphene, quartz, magnetite, and zircon. As differentiation continued in the akeritic magma, nordmarkite was formed. This rock is more silicic and alkalic than the akerite, as indicated by its higher sodic plagioclase content and by the presence of aegirine-augite. The late sequence of intrusion is indicated by the appearance of highly alkalic aegirine-augite syenite that is characterized by the absence of sodic-calcic feldspar and the presence of accessory melanite, noselite, and sodalite. The syenite also contains more $\mathrm{K}_{2} \mathrm{O}$ and $\mathrm{Na}_{2} \mathrm{O}$ than rocks of the early sequence, and it has a large amount of primary $\mathrm{SO}_{3}$ and $\mathrm{Cl}$. Many dikes of aegirineaugite syenite and pegmatites cut across the akerite and country rock.

The P'ing-yang deposits (approx lat $35^{\circ} 59^{\prime}$ N., long $111^{\circ} 45^{\prime}$ E.) are about 20 miles southeast of P'ing-yang (Lin-fen), south Shansi (Nyström, 1947, p. 87-89). Upper Ordovician limestone here is penetrated by akerite stocks and volcanic necks. The akerite is remarkably similar to the $\mathrm{Hu}$-yeh-shan akerite, except that a series of derivatives from the P'ing-yang akerite consists of granite-aplite, felsic porphyries, and banatite porphyry. The quartz-porphyry contains phenocrysts of perthitic potassium feldspars in a groundmass of quartz, alkalic feldspar, some plagioclase, and a few grains of other minerals. The banatite porphyry is a variety of diorite that consists chiefly of oligoclase, potassium feldspar, quartz, and common hornblende. A highly analcitized aegirine-augite syenite, however, was formed during the late stage of akeritic magma differentiation. In short, the P'ing-yang 
intrusive rocks are characterized by greater differentiation along granitic and dioritic trends than are those in the Tzu-chin-shan and Hu-yehshan areas.

Lin-hsien-Hsing-tai (approx lat $36^{\circ} 00^{\prime}-37^{\circ} 00^{\prime} \mathrm{N}$., long $113^{\circ} 45^{\prime}-114^{\circ}$ $40^{\prime} \mathrm{E}$.) is an area elongated north-south at the junction of Shansi, Hopeh, and Honan Provinces. Thin- to thick-bedded dolomitic and argillaceous Ordovician limestone in this area forms part of a northeast-trending anticlinal system. Syenite stocks and dikes; which intrude the limestone, are generally similar to the P'ing-yang akerite but are in part granitic and dioritic. Many north-south and east-west fractures cut across the alkalic pluton and limestone country rock.

Although information on rare-element minerals in these areas is not available, the author believes that the volcanic necks of brecciated syenite in the Tzu-chin-shan, Hu-yeh-shan, and P'ing-yang alkalic plutons are very likely similar to necks of porphyritic cancrinite syenite in the Bearpaw Mountains, Mont. (Pecora, 1962). The latter are part of a composite alkalic stock in which the silicate-carbonate-sulfide minerals are chiefly cancrinite, aegirine, biotite, muscovite, potassium feldspar, zircon, calcite, burbankite, pyrochlore, pyrrhotite, pyrite, apatite, and ilmenite. These minerals were formed by early crystallization of silicate minerals in a magma capable of producing a residual fluid high in $\mathrm{CO}_{2}, \mathrm{~S}, \mathrm{~F}, \mathrm{P}, \mathrm{Ca}, \mathrm{Fe}, \mathrm{Mg}, \mathrm{Si}, \mathrm{Al}, \mathrm{K}$, and $\mathrm{Na}$. Later fractionation of this fluid, relatively rich in $\mathrm{CO}_{2}$ and $\mathrm{H}_{2} \mathrm{~S}$, formed a great variety of mineral assemblages (Pecora, 1962, p. 99-101).

Carbonate fissure-filling or replacement veins most likely occur in the Ordovician limestone in the areas of $\mathrm{Hu}$-yeh-shan, P'ing-yang, and Lin-hsien-Hsing-tai. An allanite-bearing contact zone was found between limestone and syenite in the Lin-hsien-Hsing-tai area (Liu, 1959). The allanite had a high content of uranium, cerium, and lanthanum.

On the basis of radiometric dating (Cheng and Li, 1964, p. 665), emplacement of the alkalic plutons and rare-element mineralization in Shansi is believed to have taken place in Cretaceous time.

\section{AREAS OF PEGMATITES}

\section{ALTAI MOUNTAINS}

The Altai Mountains (lat $48^{\circ} 00^{\prime}$ N., long $90^{\circ} 00^{\prime}$.E.) are in the northeast part of Sinkiang Uighur Autonomous Region at altitudes of 1,000 to 3,500 meters. The core rocks consists of Precambrian granitoid gneiss, schist, migmatites, aplite dikes, and granite plutons. These basement rocks are unconformably overlain by marine Ordovician and Silurian phyllite slate, quartzose sandstone, and limestone in the north and by marine Devonian shale, sandstone, and limestone with inter- 
layers of volcanic tuff and flows in the central part and in the south. Marine Carboniferous shale, sandstone, limestone, tuff, and lava flows are also present in the central part and in the south, unconformably overlying the Devonian beds. Folding of these strata took place mainly during the Hercynian deformation and was accompanied by largescale granite intrusion and well-formed pegmatitic injection. Along the flanks of these folds, northwest-trending block faults are common.

Rare-element minerals occur predominantly in muscovite pegmatites (China Bureau of Mineral Resources, Ministry of Geology, 1957). Mineral assemblages consist of quartz, microcline, muscovite, tourmaline, apatite, garnet, beryl, chrysoberyl, bismuthinite, and columbitetantalite. These are associated with fluorite, lepidolite, phenakite, monazite, samarskite, topaz, ilmenorutile, spodumene, and some lithium tourmaline.

\section{HAI-CH'ENG}

At Hai-ch'eng (lat $40^{\circ} 52^{\prime}$ N., long $122^{\circ} 45^{\prime}$ E.), Liaoning Province, Precambrian Ta-shih-chiao dolomite, gneiss, schist, and migmatites were subjected to pervasive granitic intrusion, accompanied by wellformed pegmatite injection and migmatization in pre-Sinian time. The trend of pegmatites is parallel to a conspicuous east-west fracture system.

The rare-element minerals occur in biotite and muscovite types of pegmatites (China Bureau of Mineral Resources, Ministry of Geology, 1957). The biotite pegmatites occur in gneiss and hornblende schist and consist of microcline, perthite, quartz, biotite, allanite, fergusonite, euxenite, and thorogummite, in association with samarskite, betafite, epidote, magnetite, hematite, specularite, calcite, kaolinite, ampangabeite, xenotime, sphene, zircon, thorite, and uranothorite. The muscovite pegmatites are generally found in biotite schist, and contain microcline, perthite, quartz, muscovite, topaz, garnet, black tourmaline, columbite, yttrotantalite, beryl, and chrysoberyl, in association with spodumene, fluorite, lepidolite, lithium tourmaline, monazite, samarskite, ilmenorutile, sphene, kaolinite, and cassiterite.

\section{AREAS OF DISSEMINATED GRAINS IN NIOBIUM-BEARING GRANITE}

The Kwang-hai deposits (approx lat $21^{\circ} 59^{\prime}$ N., long $112^{\circ} 43^{\prime}$ E.) about 4.5 miles northwest of Kwang-hai, Kwangtung Province-are in niobium-bearing granite. The granite is in contact with Holocene marine beach sand and alluvial clay, silt, sand, and gravel on the east; metamorphosed Cambrian fine-grained sandstone on the north; and Cretaceous granite on the west and south. The niobium-bearing granite is an elongate intrusive mass that occupies about 1-2 square miles and 
trends north; it is equigranular, albitized, and deeply weathered. Mineralogically, it is composed of 43 percent microcline, 23 percent albite and other alkalic feldspars, 29 percent quartz, and 5 percent biotite and muscovite. Principal rare-element minerals are samarskite, columbite, yttrocolumbite, xenotime, monazite, zircon, and thorite, in association with cassiterite and wolframite (Chen and others, 1964, p. $454-455)$.

\section{SOME RARE-ELEMENT MINERALS}

These notes are intended to provide information on newly discovered or unusual properties of minerals that are named for localities in mainland China and are generally unfamiliar to Western readers. Baotite(Pao-t'ou-k'uang): $\left.\mathrm{Ba}_{4} \mathrm{Ti}, \mathrm{Nb}\right)_{8}\left(\mathrm{Si}_{4} \mathrm{O}_{12}\right) \mathrm{ClO}_{16}$. Tetragonal. A rare silicate of barium, titanium, and niobium with chlorine. 10.8-11.5 percent $\mathrm{Nb}_{2} \mathrm{O}_{5}$. In carbonate veins, and with galena and pyrite in quartz veins associated with alkalic rocks. Fleischer and Chro (1960, p. 754); Parker and Fleischer (1968, p. 32). Beiginite: A rare-earth fluocarbonate that contains 29.10 percent $\mathrm{Ce}_{2} \mathrm{O}_{3}, 35.71$ percent $[\mathrm{Ce}]_{2} \mathrm{O}_{3}$, and 0.18 percent $[\mathrm{Y}]_{2} \mathrm{O}_{3}$. Tetragonal. As very fine aggregates in association with oborite, aeschynite, and parisite; mainly in iron ore and fluorite veins. Color yellowish brown; green yellow in thin section. Cleavage (001) perfect. Hardness 4.5. Anisotropic; $\omega=1.7169, \epsilon=1.7910$. Weak pleochroism. Uniaxial positive. Insoluble in hydrochloric acid but slightly soluble in hot strong sulfuric acid with effervescence. Infusible. No inclusions. Resembles bastnaesite, except for lower index of extraordinary ray. Ho (1935); Wang (1958).

Fenghuangite (Fenghuangshih) (table 1): $(\mathrm{Ca}, \mathrm{Ce}, \mathrm{La}, \mathrm{Th})_{5}\left[(\mathrm{Si}, \mathrm{P}, \mathrm{C}) \mathrm{O}_{4}\right]_{3}$ $(\mathrm{OH})$ as given by Fleischer (written commun., 1968); a variety of thorium-rich britholite. Incorrectly given as fenghuanglite in Western literature (Fleischer, written commun., 1968). As yellow to brown aggregates. Generally metamict, but recrystallization occurs at temperatures of $800^{\circ}$ to about $900^{\circ} \mathrm{C}$. Fracture conchoidal. Luster waxy. Hardness about 5. Basal cleavage distinct. Uniaxial negative. Rarely, weak birefringence. Index of refraction 1.65-1.75, increasing to 1.78 or more after heating. Dissolves slowly in cold dilute hydrochloric acid with slight effervescence, readily in concentrated hydrochloric, sulfuric, and nitric acids. Peng and Liu (1962); Fleischer (written commun., 1968); Frondel, Fleischer, and Jones (1967, p. 18); Fleischer and Chao (1960, p. 754-755).

Jiningite (table 1): A variety of thorite high in ferric oxide. As tabular crystals in association with zircon, tysonite, microcline, muscovite, 
quartz, and garnet in muscovite pegmatite. Color reddish brown. Fracture conchoidal. Luster resinous. Hardness about 4. Soluble in hot phosphoric acid with color change to yellow. Kuo (1959); Frondel, Fleischer, and Jones (1967, p. 38); Fleischer and Chao (1960, p. 755).

Niobo-aeschynite (table 1): $(\mathrm{Ce}, \mathrm{Y}, \mathrm{Ca}, \mathrm{Fe}, \mathrm{Th})(\mathrm{Nb}, \mathrm{Ti})_{2} \mathrm{O}_{6}$. Niobium analog of aeschynite. As tabular crystals and aggregates in radiated form. Associated with aegirine, magnetite, martite, pyrite, barite, calcite, and phlogopite within contact-metasomatic carbonate rocks near iron ores. Color black. Translucent in small fragments. Cleavage (010) perfect. Streak brown. Luster adamantine. Fracture conchoidal. Brittle. Nonmagnetitic. Biaxial negative. $2 V$ is about $80^{\circ}$. Pleochroism from dark brown to yellowish red. Average index of refraction greater than 2. Dispersion $v$ greater than $r$. Generally anisotropic but $\mathrm{X}$-ray pattern indicates it is amorphous. After heating 6 hours at $950^{\circ} \mathrm{C}$, shows orthorhombic symmetry; powder X-ray pattern shows strongest lines (relative strength indicated in parentheses) at $3.01 \AA$ (9), $2.91 \AA$ (10), and $1.55 \AA$ (8). Chang (1962a, 1963); Frondel, Fleischer, and Jones (1967, p. 56); Parker and Fleischer (1968, p. 35).

Oborite: (Ce,La,Nd ...) $\mathrm{PO}_{4}$, containing 30.43 percent $\mathrm{Ce}_{2} \mathrm{O}_{3}$, 0.32 percent $\left[\mathrm{Y}_{2} \mathrm{O}_{3}\right.$, and 34.41 percent $[\mathrm{La}, \mathrm{Nd}, \mathrm{Pr}]_{2} \mathrm{O}_{3}$. Similar to monazite but is uniaxial and hexagonal. As very fine aggregates in association with beiyinite, aeschynite, and parisite; mainly in iron ores and fluorite veins. Color greenish yellow. Cleavage $(10 \overline{1} \overline{1})$ perfect. Hardness 4.5. $\omega=1.7948, \epsilon=1.8500$. Uniaxial positive. Solubility in hydrochloric acid much lower than that for beiyinite. Infusible. A few gas inclusions. Ho (1935); T. F. Wang (1958); Fleischer (written commun., 1968).

Sinicite (table 1): A variety of aeschynite enriched in uranium; an alternative formula given by Fleischer (written commun., 1968): $(\mathrm{Ce}, \mathrm{Y}, \mathrm{U}, \mathrm{Th})(\mathrm{Ti}, \mathrm{Nb})_{2}(\mathrm{O}, \mathrm{OH})_{7}$. As masses mainly in blocky potassium feldspar zone of biotite pegmatites. Associated with potassium feldspar, albite, quartz, biotite, muscovite, topaz, and rare-element-bearing minerals. Color dark brown to reddish brown. Fracture conchoidal. Brittle. Streak reddish brown. Luster resinous. Hardness about 6. Kuo and Chung (1957b); Fleischer (written commun., 1968); Frondal, Fleischer, and Jones (1967, p. 36); Parker and Fleischer $(1968$, p. 32); T. F. Wang (1958).

Tantalian aeschynite (table 1): $(\Sigma \mathrm{Ce}, \mathrm{Ca}, \Sigma \mathrm{Y})(\mathrm{Ti}, \mathrm{Nb}, \mathrm{Ta})_{2} \mathrm{O}_{6}$. As irregular platy crystals in pegmatites and alluvial sand; muscovite pegmatites are probably the main provenance. Commonly 
associated with columbite, samarskite, yttrotantalite, and potassium feldspar. Color yellowish brown, but earthy yellow on weathered surface. Luster resinous. Fracture conchoidal. Index of refraction greater than 2. Fluorescent X-ray spectrographic analysis indicates the following values, in percent: La, $4.6 ; \mathrm{Ce}, 24.4 ; \mathrm{Pr}, 6.3 ; \mathrm{Nd}, 18.5 ; \mathrm{Sm}, 6.6 ; \mathrm{Eu}, 0.3 ; \mathrm{Gd}, 4.7 ; \mathrm{Tb}, 0.6$; Dy, $3.4 ; \mathrm{Ho}, 1.0 ; \mathrm{Er}, 1.8 ; \mathrm{Tm}, 0.2 ; \mathrm{Yb}, 1.4 ; \mathrm{Lu}, 0.2$; and $\mathrm{Y}, 7.5$. Chang and Tung (1964).

Toddite (table 1): [Fe, $\mathrm{Mn}(\mathrm{UO})](\mathrm{Nb}, \mathrm{Ta})_{2} \mathrm{O}_{6}$. A mixture of samarskite and columbite. Orthorhombic. As tabular or blocky crystals in muscovite pegmatites; associated with muscovite, potassiumfeldspar, albite, quartz, chrysoberyl, beryl, monazite, black tourmaline, specularite, garnet, and samarskite. One toddite-bearing pegmatite 0.7 to 1.6 meters in width and about a hundred meters in length, emplaced in Precambrian biotite gneiss, strikes N. $80^{\circ} \mathrm{W}$. and dips $25^{\circ} \mathrm{NE}$. The contact between pegmatite and country rock is generally sharp; locally the country rock is partly mineralized with abundant garnet, in part replaced by biotite. Toddite crystals occur commonly at the contact between potassiumfeldspar and blocky quartz zones, and in the upper part of the potassium feldspar zone, associated with muscovite, beryl, and chrysoberyl. Crystals are 2 to 3 millimeters wide and 1 to 3 centimeters long. Color black. Hardness about 6. Streak black. Fracture subconchoidal. Compared to columbite or tantalite, the ratio of ferric oxide to ferrous oxide is high, probably as result of oxidation of ferrous iron. Kuo and Chung (1957a); Frondel, Fleischer, and Jones (1967, p. 35).

Yinshanite (table 1): A calcium-rich variety of thorite. Incorrectly given as Yanshainshynite (Fleischer, 1961). New calcium-rich thorium mineral found in biotite type of pegmatite. Compared to thorite and calcium-thorite, high in $\mathrm{P}_{2} \mathrm{O}_{5}$ and $\mathrm{CaO}$; compared to phosphothorite, contains considerable $\mathrm{CaO}$ and $\mathrm{U}_{8} \mathrm{O}_{8}$. Kuo (1958b, 1959).

\section{REFERENCES CITED}

Academia Sinica, Institute of Geology, 1959 [Geotectonic frameworks of China]: Peking, Sci. Press, 2 v. (320 p.) (in Chinese; Russian translation in 1962).

Cameron, E. N., Jahns, R. H., McNair, A. H., and Page, L. R., 1949, Internal structure of granitic pegmatites: Econ. Geology Mon. 2, 115 p.

Chang, P. S., 1958 [Aeschynite from Inner Mongolia, China]: Ti Chih Lun P'ing [Geol. Review], v. 18, no. 5, p. 360-364 and 383 (in Chinese). 1962a, Niobo-aeschynite: Sci. Sinica, v. 11, no. 7, p. 969-976.

1962b [A Thonum-poor monazite]: K'o Hsüeh T'ung Pao (Scientia) 1962 , no. 10, p. 42-44 (in Chinese).

1963 [Discussion on aeschynite-priorite minerals]: Acta Geol. Sinica, v. 43, no. 1, p. 90-97 (in Chinese). 
Chang, Ching, and Tung, Wu, 1964 [Tantalian aeschynite] : K'o Hsüeh T'ung Pao (Scientia) 1964, no. 1, p. 71-73 (in Chinese).

Chen, M. H., and Chu, Hsia, 1950, Foochow: China Geol. Survey, General geological map of China NG-50, scale 1:1,000,000.

Chen, T. C., Ting, H. S., Kao, C., and Sun, L. J., 1964 [Niobium granite, a discovery of samarskite granite]: K'o Hsüeh T'ung Pao (Scientia )1964, no. 5, p. 452-455 (in Chinese).

Cheng, Y. C., 1953 [Problems on prospecting iron ore deposits in China] : Acta Geol. Sinica, v. 33, no. 2, p. 120-133 (in Chinese).

Cheng, Y. C., and Li, Pu, 1964 [Geochronological datings in China] : K'o Hsiieh T'ung Pao (Scientia) 1964, no. 8, p. 659-666 (in Chinese).

China Bureau of Mineral Resources, Ministry of Geology, 1957 [Geochemistry and types of rare-earth mineral deposits in China, related to the mode of occurrence and prospecting]: Ti Chih Chih Shih [Geol. Knowledge] 1957, no. 11, p. 5-12 (in Chinese).

Fleischer, Michael, 1961, New mineral names: Am. Mineralogist, v. 46, nos. 9 and 10, p. 1200-1201.

Fleischer, Michael, and Chao, E. C. T., 1960, New mineral names: Am. Mineralogist, v. 45 , nos. 5 and 6, p. 753-756.

Frondel, J. W., Fleischer, Michael, and Jones, R. S., 1967, Glossary of uraniumand thorium-bearing minerals [4th ed.]: U.S. Geol. Survey Bull. 1250, 69 p.

Ho, T. L., 1935 [Note on some rare-earth minerals from Beiyin Obo, Suiyuan] : Geol. Soc. China Bull., v. 14, no. 2, p. 279-282 (in Chinese with English summary).

Holland, H. D., and Borcsik, Maria, 1965, On the solution and deposition of calcite in hydrothermal systems, in Symposium-Problems of postmagmatic ore deposition, with special reference to the geochemistry of ore veins, Prague, 1963: Prague, Czechoslovakia Geol. Survey, v. 2, p. 364-374.

Hsieh, C. Y., 1943, Tin placer deposits in Fuhochungkiang area, northeastern Kuangsi and southern Hunan, and with a note on the distribution of tin belts in China: Geol. Soc. China Bull., v. 23, nos. 1, 2, p. 79-93.

Hsü, K. C., and Ting, I., 1943 [Geology and tungsten deposits of southern Kiangsi] : China Geol. Survey Mem., ser. A, no. 17, 360 p. (in Chinese with English summary).

Hsü, K. O., Sun, Nai, Wang, T. T., and Hu, S. C., 1963 [Investigation of the polycyclic granite intrusions of southern China, with special notes on their ages of intrusions, distribution, characteristics, and their genetic relations to mineral deposits] : Acta Geol. Sinica, v. 43, no. 1, p. 1-26; no. 2, p. 141155 (in Chinese with English summary).

Huang, T. K., 1948, Kueilin: China Geol. Survey, General geological map of China NG-49, scale $1: 1,000,000$.

Kuo, C. C., 1953 [Study on some rare-earth minerals of Sui-yuan Province] : Acta Geol. Sinica, v. 33, no. 2, p. 134-143 (in Chinese).

1957 [Pegmatites in south Inner Mongolia]: K'o Hsüeh T'ung Pao (Scientia) 1957, no. 1, p. 20 (in Chinese).

1958a [Genesis and types of Inner Mongolian pegmatites] : K'o Hsiieh T'ung Pao (Scientia) 1958, no. 3, p. 93-95 (in Chinese).

1958b [Some problems of the study of rare-earth minerals and geochemical researches] : Ti Chih Lun P'ing [Geol. Review], v. 18, no. 5, p. 338-350 (in Chinese).

1959 [Jiningite-new variety of thorite]: K'o Hsüeh T'ung Pao (Scientia) 1959, no. 6, p. 206-207 (in Chinese). 
Kuo, C. C., and Chang, Ching, 1957 [Study on the thorium minerals in China]: K'o Hsiieh T'ung Pao (Scientia) 1957, no. 3, p. 92 (in Chinese).

Kuo, C. C., Chang, Ching, and Li, M. W., 1957 [Age of the pegmatites in south Inner Mongolia] : K'o Hsüeh T'ung Pao (Scientia) 1957, no. 12, p. 377-378 (in Chinese).

Kuo, C. C., and Chung, T. C., 1957a [Study on toddite of Inner Mongolia, China] : Ti Chih Chih Shih [Geol. Knowledge] 1957, no. 6, p. 6-9 (in Chinese).

$-1957 \mathrm{~b}$ [Sinicite-a new uranium mineral]: K'o Hsüeh T'ung Pao (Scientia) 1957, no. 12, p. 378 (in Chinese).

Lee, Y. Y., 1957 [High-temperature replacement iron ore deposits in the vicinity of Pao-t'ou, Inner Mongolia (abs.)]: Ti Chih Lun P'ing [Geol. Review], v. 17, no. 2, p. 217 (in Chinese).

Lee, Y. Y., Wung, L. S., and Ho, Y. C., 1957 [Precambrian stratigraphy of southwestern Inner Mongolia]: Acta Geol. Sinica, v. 37, no. 3, p. 241-268 (in Chinese with English summary).

$\mathrm{Li}, \mathrm{Pu}, 1965$, Geochronological data by the $\mathrm{K}-\mathrm{Ar}$ dating method: Sci. Sinica, v. 14, no. 11, p. 1663-1672.

Li, Yang, 1967, Uranium deposits in communist China: Energie Nucleaire, v. 9, no. 4, p. 279.

Liu, C. L., 1959 [Allanite-bearing skarn]: K'o Hsüeh T'ung Pao (Scientia) 1959, no. 4, p. 132-133 (in Chinese).

Nan, Y. C., and Wu, L. P., 1944 [On the discovery of uranium minerals in the Fu-ho-chung area] : Ti Chih Lun P'ing [Geol. Review], v. 9, nos. 1, 2, p. 85-92 (in Chinese).

Nyström, E. T., 1947. Some alkaline rocks of Shansi Province, North China: Geol. Soc. China Bull., v. 27, p. 85-92.

Parker, R. L., and Fleischer, Michael, 1968, Geochemistry of niobium and tantalum: U.S. Geol. Survey Prof. Paper 612, 43 p.

Pecora, W. T., 1962, Carbonatite problem in the Bearpaw Mountains, Montana, in Engel, A. E. J., James, Harold, and Leonard, B. F., eds., Petrologic studies-A volume in honor of A. F. Buddington: New York, Geol. Soc. America, p. 83-104.

Peng, C. J., 1959 [Discovery of thorium-bearing carbonatites] : K'o Hsüeh T'ung Pao (Scientia) 1959, no. 6, p. 208 (in Chinese).

Peng, C. J., and Liu, Y. L., 1962, Fenghuangite, a new apatite-like mineral of cerium earths and thorium: Sci. Sinica, v. 11, no. 5, p. 677-686.

Show, S. C., and Liu, Y. C., 1962 [Some new geological observations in Inner Mongolia] : Acta Geol. Sinica, v. 42, no. 4, p. 379-387 (in Chinese).

Sun, C. C., 1934 [Geology of Suiyuan and southwest Chahar] : China Geol. Survey Mem., ser. A, no. 12, 80 p. (In Chinese with English summary).

Sze, Y. T., 1957 [Geochemistry and mineralogy of the pegmatites in north Inner Mongolia]: K'o Hsüeh T'ung Pao (Scientia) 1957, no. 3, p. 91-92 (in Chinese).

Ting, T. H., 1933 [On the iron ore deposits of Beiyin Obo, Suiyuan] : China Geol. Survey Bull., no. 23, p. 53-58 (in Chinese with English summary).

Tu, Kwang-chi, and Liu, Y-mao, 1965, Some problems pertaining to the genesis of wolframite deposits of southern Kiangsi, China, in Symposium-Problems of postmagmatic ore deposition, with special reference to the geochemistry of ore veins, Prague, 1963: Prague, Czechoslovakia Geol. Survey, v. 2, p. 263-267.

Wang, C. C. 1947. On the magmatic differentiation of the Tzuchinshan alkaline rocks, Lin-hsien, Shansi : Geol. Soc. China Bull., v. 27, p. 229-242. 
Wang, T. F., 1958 [A list of rare-element minerals discovered in the past 30 years]: Ti Chih Lun P'ing [Geol. Review], v. 18, no. 6, p. 37-414 (in Chinese).

1964 [Petrological characteristics of fergusonite granite in Nan-ling] : K'o Hsüeh T'ung Pao (Scientia) 1964, no. 5, p. 449-452 (in Chinese).

Wu, L. P., 1957 [Problems of tungsten deposits in south Kiangsi] : Ti Chih Chih Shih [Geol. Knowledge] 1957, no. 1, p. 9-10 (in Chinese).

1964, Salient latitudinal geotectonic zones in China with notes on the related magneto-gravity anomalies: Sci. Sinica, v. 13, no. 6, p. 979-992.

Young, Chiah, Lu, T. W., Liu, P. K., and Hsieh, K. C. 1957 [Geology of Pai-yuno-po] : K'o Hsüen T'ung Pao (Scientia) 1957, no. 18, p. 572-573 (in Chinese). 